\title{
5- Türkçe ve Türk kültürü ders kitaplarındaki özel adların kültürel unsur olarak incelenmesi
}

\section{Şeyda YEŞILYURT ${ }^{1}$}

APA: Yeşilyurt, Ş. (2021). Türkçe ve Türk kültürü ders kitaplarındaki özel adların kültürel unsur olarak incelenmesi. RumeliDE Dil ve Edebiyat Araştırmaları Dergisi, (Ö10), 81-117. DOI: 10.2900o/rumelide.1011438.

$\ddot{\mathbf{O z}}$

Ad bilim (onomastik), özel adları inceleyen bir bilim dalıdır. Özel adlar ve adlandırmalar, toplum hafızasından beslenir. Milletlerin, dillerin, dinlerin, insanların, hayvanların, gök bilimsel kavramların, coğrafî mekânların, mimarî mekânların, bayramların, kurum ve kuruluşların, eser ve kahramanların adları gibi bir toplumun hafizasından beslenen adlandırmaların kültürel ve tarihsel bir değeri vardır. Bu nedenle kültüre dair incelemelerde özel adlar, büyük önem arz etmektedir. Alan yazında, yurt dışındaki Türk çocuklarına okutulmak üzere hazırlanan Türkçe ve Türk Kültürü ders kitaplarındaki özel adların incelenmediği görülmüştür. Bu çalışmayla Türkçe ve Türk kültürü kitaplarında yer alan özel adların neler olduğunu belirlemek, millî kültür ögelerimizin sembolü olan ancak kitaplarda yer almayan özel adlara dair eksiklikleri tespit ederek dikkat çekmek ve özel adların kültürümüz için önemini ortaya koymak amaçlanmıştır. Bu amaçla Türkçe ve Türk Kültürü (2019) ders kitaplarındaki ( 8 seviye ve 2 hazırlık kitabı) metinler ve etkinlikler incelenmiştir. Çalışma nitel bir araştırma olup doküman incelemesi yöntemi kullanılmıştır. Metinlerin analizinde, içerik analizinden yararlanılmış, kitaplarda geçen özel adlar 15 başlık altında sınıflandırılmış ve yorumlanmıştır. Kitapların geneline baktığımızda Türk kültürüne ait özel adların verildiği ancak kitaplara dağılımında orantısızlık olduğu görülmektedir. En çok özel adın " 343 ” adla Türkçe ve Türk Kültürü-8 kitabında geçtiği tespit edilmiştir. Bunların \%22'si meşhur kişiler, \%19’u mekân adı, \%10’u ülke adıdır. Diğer oranlar \%10’un altındadır ve yakın miktardadır. Belirlenen 15 başlık maddesinden 14'ü kitapta geçmektedir. Kitapta yer almayan başlık “Hayvan Adı" maddesidir. Kitabın sayfa sayısına oranla \% 149 oranında özel ad kitapta yer almaktadır. Çalışmanın sonucunda kitaplarda yer alan özel adların dağılımlarında farklılıklar olduğu, özellikle "Hazırlık Kitapları 1-2" ve "Türkçe ve Türk kültürü 1-2" kitaplarındaki özel adların diğerlerinden daha az olduğu "Türkçe ve Türk kültürü 3-4-5-6-7-8" özel adların daha fazla kullanıldığı tespit edilmiştir. Özellikle "İslamiyet, Hz. Muhammed, Allah; Mustafa Kemal Atatürk, Türk, Türkçe, Cumhuriyet Bayramı” gibi Türk-İslam kültürünün sembolü, temel taşı olan özel adların, bazı kitaplardaki metin ve etkinliklerde hiç yer almadığı belirlenmiştir. Çalışmada özel isimler, sıklık açısından ele alınmamıştır, bundan sonra yapılacak çalışmalarda özellikle "Türk, Türkiye, Türkçe" gibi özel adların her bir kitapta kaçar kez kullanıldığının tespit edilmesi önerilmektedir.

Anahtar kelimeler: Türkçe ve Türk kültürü, ders kitapları, onomastik, özel ad, kültür aktarımı

Dr. Öğr. Gör., Gazi Üniversitesi, TÖMER (Ankara, Türkiye), syesilyurt@gazi.edu.tr, ORCID ID: oooo-ooo1-7721-5323 [Araştırma makalesi, Makale kayıt tarihi: 13.09.2021-kabul tarihi: 20.10.2021; DOI: 10.29000/rumelide.1011438]

Adres $\mid$ Address

RumeliDE Dil ve Edebiyat Araştırmaları Dergisi Osmanağa Mahallesi, Mürver Çiçeği Sokak, No:14/8 Kadıköy - ISTANBUL / TÜRKIYE 34714 e-posta: editor@rumelide.com tel: +90 $5057958124,+902167730616$

RumeliDE Journal of Language and Literature Studies Osmanağa Mahallesi, Mürver Çiçeği Sokak, No:14/8

Kadıköy - ISTANBUL / TURKEY 34714

e-mail: editor@rumelide.com,

phone: +90 5057958124 , +90 2167730616 


\title{
Examination of proper nouns in Turkish and Turkish culture textbooks as cultural elements
}

\begin{abstract}
Onomastics is a branch of science that studies proper names. Proper names and denominations are fed from the memory of the society. Namings fed from the memory of a society, such as the names of nations, languages, religions, people, animals, astronomical concepts, geographical places, architectural places, holidays, institutions and organizations, works and heroes, have a cultural and historical value. For this reason, proper names are of great importance in cultural studies. In the literature, it has been observed that proper names in the Turkish and Turkish Culture textbooks prepared to be taught to Turkish children abroad are not examined. With this study, it is aimed to determine what the proper names in Turkish and Turkish culture books are, to draw attention to the deficiencies about the proper names that are the symbols of our national cultural elements but are not included in the books, and to reveal the importance of proper names for our culture. For this purpose, texts and activities in Turkish and Turkish Culture (2019) textbooks (8 level and 2 preparatory books) were examined. When we look at the books in general, it is seen that special names belonging to Turkish culture are given, but there is a disproportionate distribution of the books. The study is a qualitative research and document analysis method was used. In the analysis of the texts, content analysis was used and the proper names in the books were classified and interpreted under the 15 headings. It has been determined that the most proper names are mentioned in the Turkish and Turkish Culture- 8 book with 343 names. Of these, $22 \%$ are famous people, $19 \%$ are place names, $10 \%$ are country names. Other rates are below $10 \%$ and are close. 14 of the 15 title items determined are mentioned in the book. The title that is not included in the book is "Animal Name". The proper name is included in the book at a rate of $149 \%$ compared to the number of pages of the book. As a result of the study, there are differences in the distribution of the proper names in the books, especially in the "Preparatory Books 1-2" and "Turkish and Turkish Culture 1-2" books are less than the others in the "Turkish and Turkish Culture 3-4-5-6-7". It has been determined that -8" proper names are used more. In particular, "Islam, Hz. Muhammed, Allah; It has been determined that proper names, which are the symbols and cornerstones of Turkish-Islamic culture such as "Mustafa Kemal Atatürk, Turkish, Turkish, Republic Day", are not included in the texts and activities in some books. In the study, proper nouns were not discussed in terms of frequency, it is recommended to determine how many times special names such as "Turk, Turkey, Turkish" are used in each book in future studies.
\end{abstract}

Keywords: Turkish and Turkish Culture, textbooks, onomastics, proper name, cultural transfer

\section{Giriş}

Türkiye dışında yaşayan Türk ailelerin çocukları, bulundukları ülkelerin amaç ve ilkelerine göre öğrenim görmektedirler. Kendilerini yaşadıkları toplumda en güzel şekilde ifade edebilmeleri, haklarını koruyabilmeleri ve iyi bir iş imkânına sahip olabilmeleri için birlikte yaşadıkları toplum dilini ileri düzeyde öğrenmeleri şarttır. Ama aynı zamanda köklerinden kopmamaları için Türkçeyi ve Türk kültürünü de öğrenmeleri gerekmektedir.

Türk kültürü, Türkçenin içine zerk olmuştur. Türkçede bulunan her bir kelime Türk kültürünü aynalamaktadır. Toplumun hiçbir alanı dilden bağımsız değildir. İnsanın varlığı dil ile mümkün olduğu

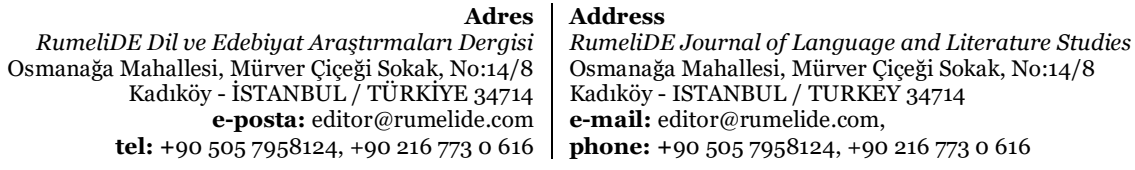


gibi, toplumların varlığı da ancak dil ile mümkün olmaktadır. Dil yoksa toplum da yoktur. Dil, bir toplumun kültür kimliğidir (Ünalan, 2005: 14). İnsanın kültürel ve bireysel kimliğinin yansıması olan adlar da kültürlerin aynası olarak toplumda değişme eğilimi gösteren önemli olgular arasında yer alırlar. Özel adlar yeni nesneleri, kişileri, oluşumları vb. belirtmek için sürekli bir ihtiyaçtır. Bu sebeple özel isimler büyük önem arz ederler (Altıntaş 2015:9). İsim, bir ad olmanın ötesinde kişiyi tarihsel ve toplumsal düzeyde bir kimliğe ait kılan önemli sembolik bir göstergedir. Bu sembolik bağlayıcılık nedeniyle "isim verme uygulamaları", belli bir kültüre, dünyaya aidiyeti ve kolektif ruha katılımı sağlama işlevine sahiptir, isim bu anlamda kişilerin sosyo-kültürel kimliğini gösteren bir varoluş parolası olmaktadır (Çelik, 2006: 57). Ad bilimi veya "Onomastik" adlı bilim dalı hayvan isimleri, yer isimleri, bitki isimleri ve insan isimleri olmak üzere ilk başta dört ana başlıkta incelenir. Bu alana ilk dikkati çeken Aristo'dur. Aristo, bugün ad, eylem, ilgeç, durum gibi, sözcük türleri ve dilbilgisi kategorileri diye bildiğimiz birtakım kavramları da ilk olarak saptayan kimsedir (Aksan, 2015). Seslerin özel birleşimi olan adlar, tek bir kişinin, hayvanın, yerin ya da nesnenin kişisel tasarımcısı olarak iş görür (Anderson, 1997:2). Buna istinaden Acipayamlı (1992), yeryüzünde ad verme olgusundan yoksun tek bir topluluk ve toplum görmenin mümkün olmadı̆̆ını ayrıca özel adların sadece işaret edici bir işlevi olmadığını aynı zamanda ismi taşıyan kişinin bölgesi, doğası, millî kökeni, sosyal ilişkileri, dinî ve felsefî görüşleri, gelenek görenekleri gibi birçok konuda bilgi içerdiğini, bir kültür taşıyıcısı niteliğinde olduğunu belirtmiştir. Özel isimlerin incelenmesi büyük önem taşısa da bu güne kadar bu konuya gereken önem verilmediğini de ifade etmiştir. Özellikle özel adlar, millî bilinci nesillere aktaran kodlardır. Ad bilim (onomastik), özel adları inceleyen bir bilim dalıdır. Özel adlar ve adlandırmalar, toplum hafızasından beslenir. Milletlerin, dillerin, dinlerin, insanların, hayvanların, gök bilimsel kavramların, coğrafî mekânların, mimarî mekânların, bayramların, kurum ve kuruluşların, eser ve kahramanların adları gibi bir toplumun hafızasından beslenen adlandırmaların kültürel ve tarihsel bir değeri vardır. Bu sebeple Türkçe ve Türk Kültürü kitaplarındaki özel adların incelenmesi önem arz etmektedir. Bu çalışmada bu kodları tespit etmek amacıyla yurt dışında yaşayan Türk çocukları için 2019'da yazılan Türkçe ve Türk kültürü ders kitaplarında yer alan özel adların incelenmesi amaçlanmaktadır.

On Yedinci Millî Eğitim Şûrası'nda Türkiye dışında yaşayan Türk çocuklarının, bulundukları ülke okullarında da Türk dili, kültür ve inançlarına yönelik eğitimleri etkin bir şekilde sürdürülmesi ve bu işin sadece ailelerin üzerine bırakılmaması kararı alınmıştır (MEB, 2007). Millî Eğitim Bakanlığı, yurt dışındaki Türk çocuklarına yönelik olarak 2006 yılında, 14.09.2006 tarih ve 360 sayılı kararla Yurt Dışındaki Türk Çocukları için Türkçe ve Türk Kültürü Öğretim Programı hazırlamıştır. Bu program 03.08.2009 tarihinde 112 sayılı kararla kaldırılarak yerine yeni bir program hazırlanmıştır. 2009 yılında 1. sınıftan 10. sınıfa kadar Türkçe dersi alacak öğrenciler için hazırlanmış Türkçe öğretim programında sinıf seviyelerine göre; 1-3. sinıflar, 4-5. sinıflar, 6-7. sinıflar ve 8 -10. sinıflar şeklinde dört grup oluşturulmuş ve kazanımlar bu gruplar içerisinde dağıtılmıştır. Ve bu doğrultuda 2010 yllında kitaplar hazırlanmıştır. Ancak Karadüz ve Ekmekçi (2015)'nin bu kitaplara yönelik eleştirel bakışları, Karadă̆ ve Baş'ın (2019) ve Türkçe ve Türk Kültürü dersine dair yaptıkları ihtiyaç analizi, 2010 yılında hazırlanan ders kitaplarının kullanılmadığını, öğretmenler tarafından resmî öğretim programının da takip edilmediği sonucunu ortaya koymuştur. Sebep olarak da Türkçe ve Türk Kültürü ders kitaplarının öğrencilerin düzeylerinin çok üstünde metinler içermesi, öğrencilerin mevcut dil seviyelerini dikkate alarak hazırlanmamış olması, hiç dil bilmeyen öğrencilerin ihtiyaçlarını karşılayamaması, öğrencilerin hazır bulunuşluk seviyelerine uygun olmaması şeklinde özetlenebilecek hususlar sıralanmıştır. Bu ve bunun dışındaki farklı çalışmaların neticesiyle 2018 yılında Millî Eğitim Bakanlığı tarafından Türkçe ve Türk Kültürü dersi için yeni bir program oluşturulmuştur. Bu programa göre yurt dışında yaşayan Türk çocuklarının temel eğitim düzeyleri, ülkelere göre değişiklik gösterebilmekte ve ülkelerin okul sistemleri

Adres $\mid$ Address

RumeliDE Dil ve Edebiyat Araştırmaları Dergisi $\quad$ RumeliDE Journal of Language and Literature Studies

Osmanağa Mahallesi, Mürver Çiçeği Sokak, No:14/8 $\quad$ Osmanağa Mahallesi, Mürver Çiçeği Sokak, No:14/8

Kadıköy - ISTANBUL / TÜRKIYE 34714 Kadıköy - ISTANBUL / TURKEY 34714

e-posta: editor@rumelide.com e-mail: editor@rumelide.com,

tel: +90 505 7958124, +90 216773 o 616 phone: +90 505 7958124, +90 2167730616 
arasında farklılıklar olabilmektedir (MEB,2018:1). Bu nedenle sınıf sistemi yerine temel eğitime karşıllk gelecek sekiz seviye üzerinden bir program oluşturulmuştur. Programın ardından ders kitaplarında da güncelleme yapılmış ve programda belirlendiği şekilde sekiz seviyenin her biri için, 2019 yllında yeni Türkçe ve Türk Kültürü kitapları hazırlanmıştır. Hiç Türkçe bilmeyen öğrenciler için de öğretmen kılavuz kitapları ve çalışma kitapları ile birlikte Türkçeye hazırlık kitapları oluşturulmuştur.

Türkçe ve Türk Kültürü kitapları üzerine yapılan birçok çalışma bulunmaktadır ancak çalışmaların çoğu 2010 yılında yazılan kitaplar üzerinedir. Arıcı (2019) ve Kolay (2018), 2010 yılında yazılan Türkçe ve Türk kültürü kitaplarındaki kültür unsurlarını incelemişlerdir. Kolay (2018:363) çalışmasında, Türkçe ve Türk Kültürü dersi için temel materyal olarak kullanılan ders kitaplarında yer alan metinler, kültür ögelerinden dil, din, tarih, örf ve âdetler, aile ve akrabalık ilişkileri, giyim kuşam, dinî ve millî bayramlar, sanat, spor, yiyecek, içecek ve beslenme, vatan, millet, bayrak, bağımsızlık, millî kurum ve kuruluşlar, Türkiye coğrafyası, tarihî ve turistik yerlere yeterince yer vermelidir, sonucuna ulaşmıştır. Arıcı (2019) ise çalışmasında millî kültür unsurlarından dil, tarih, gelenek ve göreneğe belirli oranlarda yer verildiğini ancak Türk sanatı ve Türk dünya görüşüne Türk Kültürü kitaplarında yeterince yer verilmediğini ifade etmiştir. 2019'da yazılan Türkçe ve Türk Kültürü kitaplarındaki kültür unsurlarına dair yapılan bir çalışma ise mevcut değildir.

\section{Çalışmanın amacı}

Bu çalışmanın amacı yurt dışında yaşayan Türkler için hazırlanmış Türkçe ve Türk Kültürü (2019) ders kitaplarındaki özel adları belirlemek, kitaplardaki bu özel adların dağılımında ve çeşitliliğinde bir farklılık olup olmadığını tespit etmektir. Çalışmanın problem cümlesi "Türkçe ve Türk Kültürü ders kitaplarında hangi özel adlar yer almaktadır?”. Alt problem cümleleri “Bu özel adların dă̆llımında kitaplar arasında farklılık var mıdır?" ve "Kitaplarda yer alan özel adların çeşitliliğ̈inde farklılık var midır?".

\section{Yöntem}

Çalışmada nitel araştırma yöntemlerinden doküman incelemesi kullanılmıştır. Doküman incelemesi, araştırılması hedeflenen olgu ve olgular hakkında bilgi içeren yazılı materyallerin analizini kapsar (Ylldırım ve Şimşek, 2011:187).

\section{İncelenen dokümanlar}

Çalışmada Millı̂ Eğitim Bakanlığı tarafından yurt dışındaki Türk çocukları için 2019 yılında hazırlanan toplam 10 adet Türkçe ve Türk Kültürü Dersi kitabı incelenmiştir. İncelenen kitaplara ait kapak görselleri şu şekildedir:

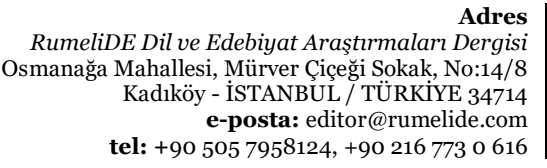

dres

Address

RumeliDE Journal of Language and Literature Studies

Osmanağa Mahallesi, Mürver Çiçeği Sokak, No:14/8

e-mail: editor@rumelide.com,

phone: +90 5057958124, +90 2167730616 

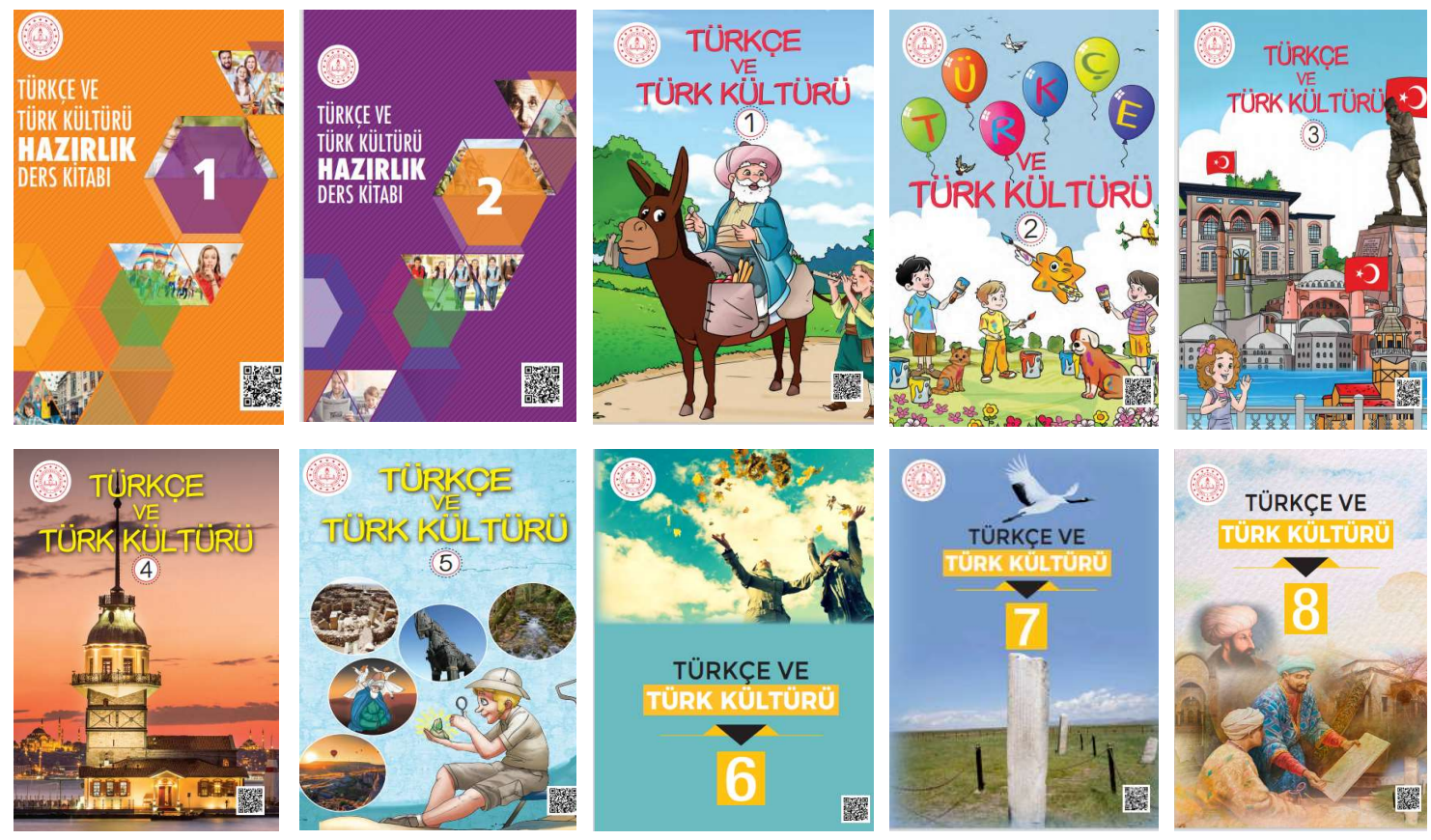

Görsel 1. Türkçe ve Türk kültürü ders kitaplarının kapakları

Türkçe ve Türk Kültürü Dersi Öğretim Programı’nın uygulanması sürecinde, kitaplarda her seviye için belirlenen 8 temanın işlenmesi öngörülmüştür. Programda seviyelere göre alt temalar oluşturularak hiyerarşik biçimde sıralanmıştır. Öğrenme öğretme sürecinde işlenmesi ve öğretim materyallerinde yer verilmesi öngörülen temalar ve bu temalarla ilgili alt temalar aşağıda sunulmuştur. Temalar alfabetik olarak sıralanmıştır ancak kitaplar hazırlanırken şu tema sıralamasının dikkate alınması önerilmektedir: "1. Ben ve Ailem, 2. Çevre, Farklılıklar ve Birlikte Yaşama, 3. Oyun ve Eğlence, 4. Bayramlar ve Kutlamalar, 5. Gezelim Görelim, 6. Geçmişe Açlan Kapı, 7. Sanat ve Edebiyat, 8. İnsan ve Doğa” (MEB Türkçe ve Türk Kültürü Öğretim Programı, 2018).

\section{Verilerin toplanması ve analizi}

Kitaplardaki verilerin incelenmesinde içerik analizinden faydalanılmıştır. Kitaplardaki özel adlar öncelikle tek tek yazılmış ardından tasnif edilmiştir. Tasnifte öncelikle öğretim ilkelerinde esas olan yakından uzağa ve somuttan soyuta ilkeleri gözetilmiştir. Sıralamada ve incelemede ele alınacak özel adları belirlemede iki uzman görüşüne başvurulmuştur. "Kişi adları" listenin başında yer almıştır. Ardından kişinin ülkesi, şehri, milliyeti, dili ve dini, kültüre ait esas unsurları belirlediği için liste bu özel isimlerle devam ettirilmiştir. Bu tasnif sonucunda özel isimler 15 başlık altında ele alınmış ve şu şekilde sınıflandırılmıştır:
1. Kişi Adları
2. Ülke Adları
3. Şehir Adları
4. Milliyet ve Mensubiyet Adları
5. Dil Adları
6. Dinle İlgili Özel Adlar

\begin{tabular}{r|l} 
Adres & Address \\
RumeliDE Dil ve Edebiyat Araşturmaları Dergisi & RumeliDE Journal of Language and Literature Studies \\
Osmanağa Mahallesi, Mürver Çiçeği Sokak, No:14/8 & Osmanağa Mahallesi, Mürver Çiçeği Sokak, No:14/8 \\
Kadıköy - İSTANBUL / TÜRKIYE 34714 & Kadıköy - ISTANBUL / TURKEY 34714 \\
e-posta: editor@rumelide.com & e-mail: editor@rumelide.com, \\
tel: +90 505 7958124, +90 216773 0 616 & phone: +90 505 7958124, +90 2167730616
\end{tabular}


7. Meşhur Kişiler

8. Mekân (Coğrafi ve Tarihi) Adları (Köy, İlçe, Cami, Medrese, Mahalle, Kıta, Yeryüzü şekilleri...)

9. Bayram Adları

10. Önemli Günler

11. Eser ve Kahraman Adları (Film, Çizgi Film, Kitap, Program)

12. Kurum Adları

13. Gazete ve Dergi Adları

14. Kanal Adları

15. Hayvan Adları

\section{Bulgular ve yorum}

Bulgular, her bir kitap için veri analizindeki 15 maddeye göre ayrı tablolar şeklinde ifade edilmiş ve yorumlanmıştır:

\section{Türkçe ve Türk kültürü hazırlık kitabı 1}

Hazırlık kitabı 168 sayfadan oluşmaktadır. Kitabın girişinde iki kıta şeklinde İstiklal Marşı yer almaktadır. Kitapta yer alan özel adlar tablolar hâlinde şu şekildedir:

Tablo 1. Kişi adları

$\begin{array}{lllllllll}\text { Ahmet } & \text { Ali } & \text { Ayhan } & \text { Aylin } & \text { Ayşe } & \text { Ayşegül } & \text { Azra } & \text { Belgin } & \text { Beste } \\ \text { Can } & \text { Defne } & \text { Deniz } & \text { Eda } & \text { Elif } & \text { Emre } & \text { Esma } & \text { Esra } & \text { Fatma } \\ \text { Gül } & \text { Hakan } & \text { Halime } & \text { Hande } & \text { Harun } & \text { Hasan } & \text { Hülya } & \text { İrem } & \text { İsmail } \\ \text { Kemal } & \text { Meltem } & \text { Meryem } & \text { Mete } & \text { Muhammet } & \text { Murat } & \text { Mustafa } & \text { Naim } & \text { Nezir } \\ \text { Oğuz } & \text { Osman } & \text { Ömer } & \text { Özlem } & \text { Seher } & \text { Selim } & \text { Selin } & \text { Sena } & \text { Tayfun } \\ \text { Veli } & \text { Yahya } & \text { Yusuf } & \text { Zehra } & \text { Zeynep } & & & & \end{array}$

Kitapta 50 özel ad, kişi adı olarak yer almaktadır. Bu isimler genel itibarıyla “Ahmet, Ali, Ayşe, Elif, Fatma, Muhammet, Fatma, Mustafa, Osman, Ömer” gibi Türk -İslam kültürüne ait Türkiye'de en çok kullanılan kişi adlarıdır.

Tablo 2. Ülke adları
Almanya
Belçika
Fransa
İsviçre
Türkiye

Kitapta 5 ülke adı yer almaktadır. Bu ülkeler, Türkçe ve Türk Kültürü kitaplarının okutulduğu yerler olması hasebiyle önem arz etmektedir. Tabii ki bu kitapların okutulduğu ülkeler sadece bu dört ülkeyle sınırlı değildir. Ancak özellikle Türk nüfusu bakımından daha yoğun ülkelerin verilmesi önemlidir. Dışişleri Bakanlığı 2020 verilerine göre Türk nüfusun çok olduğu 20 ülke sıralamasında Almanya ilk sırada Fransa ikinci, Belçika yedinci, İsviçre dokuzuncu sırada yer almaktadır. Kitap içinde “Türkiye”nin adının geçmesi de özellikle kitabın Türk kültürü kitabı olması sebebiyle önemlidir.

Tablo 3. Şehir adları

\begin{tabular}{|c|c|c|c|c|}
\hline $\begin{array}{l}\text { Adana } \\
\text { İstanbul }\end{array}$ & $\begin{array}{l}\text { Adryaman } \\
\text { İzmir }\end{array}$ & $\begin{array}{l}\text { Ankara } \\
\text { Konva }\end{array}$ & $\begin{array}{l}\text { Brüksel } \\
\text { Köln }\end{array}$ & $\begin{array}{l}\text { Gaziantep } \\
\text { Nevsehir }\end{array}$ \\
\hline & & & & \\
\hline
\end{tabular}

\footnotetext{
Adres | Address

RumeliDE Dil ve Edebiyat Araştırmaları Dergisi Osmanağa Mahallesi, Mürver Çiçeği Sokak, No:14/8 Kadıköy - ISTANBUL / TÜRKIYE 34714 e-posta: editor@rumelide.com

RumeliDE Journal of Language and Literature Studies Osmanağa Mahallesi, Mürver Çiçeği Sokak, No:14/8 Kadıköy - ISTANBUL / TURKEY 34714

e-mail: editor@rumelide.com tel: +90 505 7958124, +90 216773 o 616 phone: +90 505 7958124, +90 2167730616
} 
Kitapta 12 şehir adı geçmektedir. Ankara ve İstanbul Türkiye'nin iki önemli şehridir. Türkçe ve Türk kültürü kitaplarında bu iki şehrin mutlaka olması gerektiği düşünülmektedir. Diğer şehirler de tarihi ve turistik özellikleri vurgulamak amacıyla kitapta yerini almıştır. Türkiye dışından ise sadece iki şehir adı verilmiştir.

Tablo 4. Milliyet adları

Belçikalı Türkiyeli

Kitapta sadece iki milliyet adı geçmektedir. Kitabın adının "Türk Kültürü” olmasına rağmen kitapta “Türk” kelimesi değil sadece Türkiyeli kelimesi yer almaktadır. Diğer ülkelerden de sadece Belçika'ya ait mensubiyet yer almaktadır.

Tablo 5. Dil adları

Türkçe

Kitapta yer alan dil adı sadece "Türkçe"dir. Diğer dil adlarından da kitapta bağlam içinde örneklerin yer alması öğrencilerin dil adlarının nasıl yapıldığını mantıksal olarak kavramalarına yardımcı olacağı düşünülmektedir.

Tablo 6. Meşhur kişiler
Evliya Çelebi
İbn-i Sina
Mesut Özil
Mevlana

Kitapta yer alan dört meşhur isim bulunmaktadır. Türk kültürünü aktaran bir kitapta sadece dört özel ismin yer almasının yeterli olup olmadığı diğer eserlerde yer alan isimler verildikten sonra sonuçta değerlendirilecektir.

Tablo 7. Mekân adları

$\begin{array}{lllll}\text { Anıtkabir } & \text { Atatürk Caddesi } & \text { Avanos } & \text { Demir Sitesi } & \text { Hamamönü Evleri } \\ \text { Hattuşa } & \text { İstanbul Boğazı } & \text { Kapadokya } & \text { Kocatepe Camisi } & \text { MiniaTürk } \\ \text { Nemrut Dağı } & \text { Ölüdeniz } & \text { Suna Akın Oyuncak } & \text { Üsküdar } & \\ & & \text { Müzesi } & & \end{array}$

Kitapta 14 mekân adı bulunmaktadır. Bu mekânlar içerisinde özellikle Anıtkabir, İstanbul Boğazı, Kapadokya, Nemrut Dağı gibi yerler Türk tarih ve coğrafyası açısından önemli yerlerdir. Yabancı ülkelerde yer alan mekân adlarına yer verilmemiştir.

Tablo 8. Bayram adları

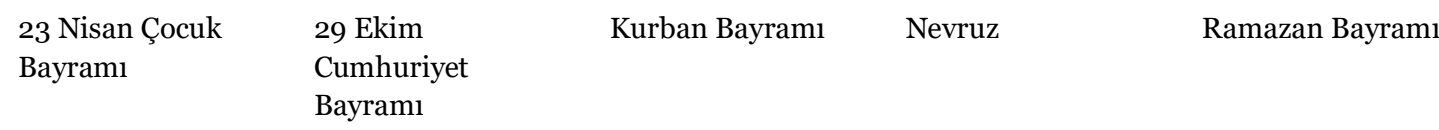

Kitapta 5 bayram adı geçmektedir. Resmî ve dinî bayramlar Türk kültürünün önemli göstergeleridir. Metinlerde iki dini ve iki resmi bayram yer almaktadır. Nevruz Bayramı da Türk tarihi için önem arz eden bir bayramdır. Türk kültürünü öğrenecek Türk gençlerinin bu bayramları mutlaka bilmeleri gerekmektedir.

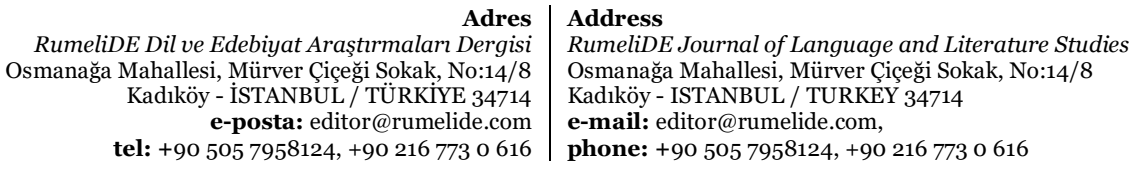


Tablo 9. Önemli günler
Anneler Günü
Babalar Günü
Öğretmenler Günü

Kitapta 3 önemli gün bulunmaktadır. Türkiye'de, ilk Anneler Günü 9 Mayıs 1955'te kutlanmıştır. 1980'li yllardan itibaren Haziran’ın üçüncü Pazar günü Babalar Günü olarak kutlanmaya başlanmıştır. İki gün de Amerika kaynaklı olarak ilk kez kutlanmaya başlamıştır. Pek çok ülkede 1994'ten beri 5 Ekim günü UNESCO tavsiyesiyle Öğretmenler Günü olarak kutlanmaktadır. Türkiye'de ilk kez Atatürk'ün doğumunun 100. yllı olan 1981 senesinde kutlanan Öğretmenler Günü için bu tarihin belirlenmesinin sebebi de Başöğretmen Mustafa Kemal Atatürk'ün Millet Mektepleri'nin Başöğretmenliği görevini kabul ettiği tarihin 24 Kasım 1928 oluşudur. Bu sebeple Öğretmenler Günü tarihi ve kutlanma amacı sebebiyle diğer iki güne daha geç bir tarihte başlasa da millî bir özellik arz etmektedir.

Tablo 10. Eser ve kahraman adları
Aslan kral
Buz Devri
Forrest Gump
Kayıp Balık Nemo
Keloğlan
Küçük Prens
O. Stephen King
Oyuncak Hikâyesi

Kitapta film, çizgi film, kitap adı ve kahramanları 8 özel isim olarak tespit edilmiştir. Bunların içinde sadece "Keloğlan" Türk kültürüne ait bir masal kahramanıdır.

Tablo 11. Hayvan adları
Çarşaf
Çomar
Pamuk
Tekir

Kitapta Türkiye'de kedi, köpek gibi evcil hayvanlara isim olarak verilen 4 özel ad bulunmaktadır. Bunlar "Çarşaf" hariç, yaygın olarak kullanılan özel adlardır.

Kitapta 109 özel ad geçmektedir. Bu özel adların \%49’unu 57 şahıs ismi， \%10’u şehir adları, \%12'si mekân adlarıdır. Diğer özel adlarının yüzdelik dilimleri \%10’un altında ve birbirine yakındır. Kitapta verileri tasnif ederken elde edilen 15 maddelik özel isim başlı̆̆ından 11'i yer almaktadır. "Dinle İlgili Özel Adlar, Kurum Adları, Gazete ve Dergi Adları, Kanal Adları” başlıklarına ait özel ad kitapta yoktur. Özel adların sayfa sayısına oranı \%70'tir.

\section{Türkçe ve Türk kültürü hazırlık kitabı 2}

Kitap 148 sayfadan oluşuyor. Kitabın girişinde iki kıta şeklinde İstiklal Marşı bulunmaktadır. Kitapta yer alan özel adlara ait tablolar ve yorumlar şu şekildedir:

Tablo 12. Kişi adları

$\begin{array}{lllll}\text { Ahmet } & \text { Alp } & \text { Ayşe } & \text { Can } & \text { Duru } \\ \text { Duygu } & \text { Eda } & \text { Elif } & \text { Emily } & \text { Emre } \\ \text { Ezgi } & \text { Gül } & \text { İrem } & \text { Joseph } & \text { Marie } \\ \text { Mehmet } & \text { Mehmet } & \text { Merve } & \text { Paul } & \text { Yiğit }\end{array}$

Kitapta şahıslara verilen 20 özel ad bulunmaktadır. Bunlardan dördü yabancı özel adlar. 16’sı Türkiye'de yaygın olarak kullanılan özel adlardır.

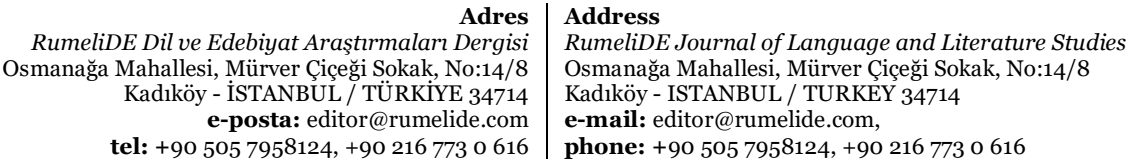


Tablo 13. Ülke adları

$\begin{array}{lllll}\text { Almanya } & \begin{array}{l}\text { Amerika Bileşik } \\ \text { Devletleri }\end{array} & \text { Fransa } & \text { İngiltere } & \text { İsviçre } \\ \text { Kaponya } & \text { Kanada } & \text { Rusya } & \text { Sirbistan } & \text { Türkiye }\end{array}$

Kitapta 10 ülke adı geçmektedir. Seçilen ülkeler genel olarak Türklerin nüfus olarak yoğun olduğu ülkeler olmakla birlikte "Sirbistan ve Japonya" gibi Türk nüfusun diğer ülkelere oranla daha az olduğu ülkeler bulunmaktadır.

Tablo 14. Şehir adları

$\begin{array}{llllllll}\text { Ankara } & \text { Antalya } & \text { Berlin } & \text { Bolu } & \text { Burdur } & \text { Hatay } & \text { İstanbul } & \text { İzmir } \\ \text { Los } & \text { Münih } & \text { Nevşehir } & \text { Osaka } & \text { Osmaniye } & \text { Paris } & \text { Selanik } & \text { Sivas } \\ \text { Angeles } & & & & & \end{array}$

Kitapta 16 şehir adı geçmektedir. Bunlardan 6'sı farklı ülkelerde bulunan şehirlerdir. Bunların içinde "Selanik" Atatürk’ün doğum yeri olması sebebiyle de Türkler için önemli bir şehirdir. Ankara, İstanbul Türkçe ve Türk kültürü kitaplarında yer alması gerektiği düşünülen iki önemli şehrimizdir.

Tablo 15. Milliyet adları
Alman
Ankaralı
Fransiz
İngiliz
Türk

Kitapta toplam 5, milliyet ve mensubiyet adlarından "Türk" ve Ankaralı" ifadesi dışında 3 farklı milliyet bulunmaktadır. Özellikle "Türk" kelimesinin kitap içinde yer alması önemlidir. Yurt dışına Türkiye'nin farklı şehirlerinden giden ailelerin kendi şehirlerini ifade etmesi için kullanılan "-lI" ile şehir birleştirme örneğinin kitapta yer alması da önem arz etmektedir.

Tablo 16. Dil adları

Türkçe

Kitapta yer alan tek dil adı "Türkçe"dir. Bu özel adın zaten kitap içeriğinde mutlaka yer alması gerekmektedir.

Tablo 17. Dinle ilgili özel adlar

Allah

Kitapta dinle ilgili özel ad olarak "Allah" lafzı geçmektedir. Milliyetleri ortaya çıkaran temel taşlar, dil, din ve ırktır. Bu nedenle inanç, kültürün ana omurgasında yer alır. Dini inançlar belli bir kültürel haritanın oluşumunda ana etkendir. Örneğin, kurban kesmek, bayramlaşmak, hacca gitmek, namaz kılmak gibi dini inançlar aynı zamanda yoğun bir kültürün oluşumuna kaynaklık eder. Her bir inanç değerinin etrafında yoğun bir kültürün yapılaştı̆̆ı görülür. Bu inançların ritüelleri, sembolleri, rutinleri, kuralları, icra yöntemleri ile baştan sona bir kültür hâline dönüştüğü görülür (Alver, 2010: 37). Bu nedenle Türk kültürünü vermek isteyen Türkçe kitaplarında dine ait özel adlara yer verilmesi gerekmektedir.

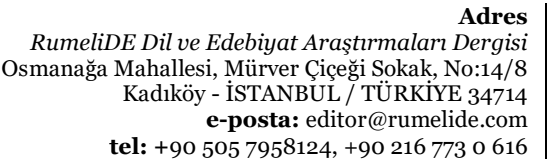

Adres

RumeliDE Dil ve Edebiyat Araştırmaları Dergisi Kadıköy - ÍSTANBUL / TÜRKIYE 34714 tel: +90 $5057958124,+902167730616$
Address

RumeliDE Journal of Language and Literature Studies

Osmanağa Mahallesi, Mürver Çiçeği Sokak, No:14/8

Kadıköy - ISTANBUL / TURKEY 34714

e-mail: editor@rumelide.com,

phone: +90 505 7958124, +90 2167730616 
Tablo 18. Meşhur kişiler

$\begin{array}{llllll}\text { Akşemsettin } & \text { Ali Rıza Efendi } & \text { Âşık Veysel } & \text { Cahit Arf } & \text { Edison } & \text { Esra Cihan } \\ \text { Grahambell } & \text { Humphry Davy } & \text { Jules Noel } & \text { Kenan Doğulu } & \begin{array}{l}\text { Mustafa Kemal } \\ \text { Atatürk }\end{array} & \text { Mustafa Sandal }\end{array}$

Şemsi Efendi Zübeyde Hanım

Kitapta tarihte veya günümüzde yer alan meşhur kişilerden 14 kişi yer almaktadır. Kitapta Mustafa Kemal Atatürk ve annesinin adı bulunmaktadır. Meşhur müzisyenlere de kitapta yer verilmiştir. Türklerin dışında Edison, Grahambell gibi dünya tarihine buluşlarıyla yön veren insanların da kitapta adı geçmektedir.

Tablo 19. Mekân adları

$\begin{array}{lllllll}\text { Akdeniz } & \text { Alaçatı } & \text { Anıtkabir } & \text { Atakule } & \text { Avrupa } & \text { Beşiktaş } & \text { Bodrum } \\ \begin{array}{l}\text { Botanik } \\ \text { parkı }\end{array} & \text { Çeşme } & \text { Çin Seddi } & \begin{array}{l}\text { Doğu } \\ \text { Anadolu }\end{array} & \begin{array}{l}\text { Dolmabahçe } \\ \text { Sarayı }\end{array} & \text { Ege } & \begin{array}{l}\text { Galatasaray } \\ \text { Lisesi }\end{array} \\ \text { Hawaii } & \text { İç Anadolu } & \text { Kapadokya } & \text { Marmara } & \begin{array}{l}\text { Mauna Kea } \\ \text { Dağı }\end{array} & \text { Plüton } & \text { Uludağ }\end{array}$

Kitapta 21 mekân adı vardır. Türkiye'nin bölgelerine verilen özel adlar, yurt dışında yaşayan Türk çocuklarının Türkiye’yi tanımaları için önemlidir. Güneydoğu Anadolu, Karadeniz hariç 5 bölgenin adı kitapta geçmektedir. "Anıtkabir" kitapta bulunmaktadır.

Tablo 2o. Bayram adları

$\begin{array}{lll}\text { Kurban Bayramı } & \begin{array}{ll}23 \text { Nisan Ulusal } \\ \text { Egemenlik ve Çocuk }\end{array} & \text { 29 Ekim Cumhuriyet } \\ \text { Bayramı } & \text { Bayramı } & \text { Ramazan Bayramı }\end{array}$

Kitapta 2 dinî ve 2 resmî, toplam 4 bayram adı geçmektedir.

Tablo 21. Önemli günler

Avrupa Şampiyonası

Önemli gün olarak sadece “Avrupa Şampiyonası” yer almaktadır.

Tablo 22. Eser ve kahraman adları

Payitaht Abdülhamit

Eser adı olarak sadece bir televizyon dizisi adı geçmektedir.

Tablo 23. Kurum adları

\begin{tabular}{|c|c|c|c|c|c|}
\hline AŞTİ & $\begin{array}{l}\text { İstanbul } \\
\text { Üniversitesi }\end{array}$ & $\begin{array}{l}\text { Orta Doğu } \\
\text { Teknik } \\
\text { Üniversitesi }\end{array}$ & Robert Koleji & $\begin{array}{l}\text { Şemsi Efendi } \\
\text { Öektebi }\end{array}$ & $\begin{array}{l}\text { Türkiye Büyük } \\
\text { Millet Meclisi }\end{array}$ \\
\hline
\end{tabular}

Kitapta 6 kurum adı geçmektedir. Türkiye'nin önemli üniversitelerinden ikisi bu isimler arasındadır. Özellikle Türkiye'nin en önemli kurumu olan Türkiye Büyük Millet Meclisi’nin kitapta yer alması önemlidir.

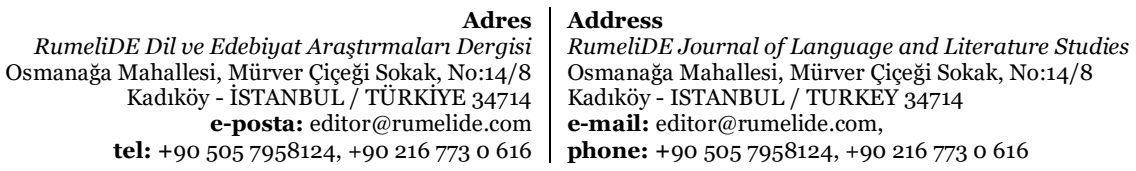


Tablo 24. Gazete ve dergi adları

Oğuzlar Ortaokulu Gazetesi

Gazete olarak bir okula ait gazete adı kitapta bulunmaktadır. Türkiye'de basılan gazete isimlerinden biri yer almamıştır.

Türkçe ve Türk Kültürü Hazırlık-2 kitabında toplam 101 özel ad geçmektedir. Bu özel adların \%22'sini mekân adları, \% 19'unu şahıs adları, \%16'sını şehir adları , \%14’ünü meşhur kişiler oluşturmaktadır. Diğer adların dağılımı \%10'unun altındadır. 15 ana başlık maddesinden 13’ü kitapta mevcuttur. Kanal ve Hayvan adları madde başlıklarına ait özel ad kitapta yoktur. Özel adların sayfa sayısına oranı \%70’tir.

\section{Türkçe ve Türk kültürü 1}

Kitap 174 sayfadan oluşmaktadır. Kitap dinleme metinleri üzerine kuruludur. Bu kitap birinci seviyeye, okuma yazma bilmeyen 6-7 yaş öğrencilerine yönelik hazırlanmıştır. Kitabın tamamında dinleme, konuşma; çizme, boyama çalışmalarına yer verilmiştir. Kitabın başında İstiklal Marşı iki kıta şeklinde yer almaktadır.

Tablo 25. Kişi adları

$\begin{array}{lllllll}\text { Ali } & \text { Alp } & \text { Aslı } & \text { Ata } & \text { Aybike } & \text { Ayşe } & \text { Fatma } \\ \text { Hakan } & \text { Hasan } & \text { Kerem } & \text { Mete } & \text { Mustafa } & \text { Ŏguzhan } & \text { Rei } \\ \text { Rüya } & \text { Yiğit } & \text { Zehra } & & & & \end{array}$

Kitapta 17 özel şahıs adı geçmektedir. Bunlardan sadece biri yabancı özel addır. Diğer isimler yaygın kullanılan özel adlardır.

Tablo 26. Ülke adları

Türkiye Almanya

Kitapta 2 ülke adı yer almaktadır. Farklı ülke isimlerine yer verilmemesi sadece Almanya olması kitabın sadece Almanya'da okutulan bir kitap olduğunu düşündürmektedir.

Tablo 27. Şehir adları

İstanbul İzmir

Kitapta şehir adı olarak 2 özel ad, sadece İzmir ve İstanbul geçmektedir. "Ankara” kitapta yer almamaktadır.

Tablo 28. Milliyet ve mensubiyet adları
Japon
Türk

Kitapta geçen iki milliyet ismi bulunmaktadır. Yukarıda ülke isimlerinde Almanya geçmesine rağmen "Alman" ifadesine değil "Japon" ifadesi geçmektedir.

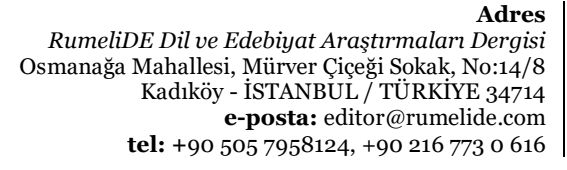

dres

RumeliDE Journal of Language and Literature Studies

Osmanağa Mahallesi, Mürver Çiçeği Sokak, No:14/8

Kadıköy - ISTANBUL / TURKEY 34714

e-mail: editor@rumelide.com,

phone: +90 $5057958124,+902167730616$ 
Tablo 29. Meşhur kişiler

Gazi Mustafa Kemal Paşa

Kitapta meşhur isim olarak tek isim "Gazi Mustafa kemal Paşa”dır.

Tablo 3o. Mekân adları

\begin{tabular}{|c|c|c|c|}
\hline Göreme Milli & Fethiye & Ölüdeniz & Sultanahmet \\
\hline
\end{tabular}

Kitapta 6 mekân adı geçmektedir. Bu mekânlardan biri dışında diğer isimler Türkiye’de bulunan cami, park, ilçe gibi mekânlardır.

Tablo 31. Bayram adları

23 Nisan

Kitapta yer alan tek bayram resmî bir bayram olan 23 Nisan'dır.

Tablo 32. Eser ve kahraman adları
Hacivat Karagöz
Keloğlan
Nasrettin Hoca

Kitapta yer alan 3 kahraman bulunmaktadır. Üçü de Türk kültürüne ait önemli kahramanlardır.

Türkçe ve Türk Kültürü- 1 kitabında 33 özel ad geçmektedir. Bu isimlerin \%52’si şahıs adları, \%18’i mekân adlarıdır. Diğer özel adların dağılım oranı birbirine yakındır. 15 madde başlığından 8’i kitapta yer almaktadır. "Dil Adı, Dinle İlgili özel Adlar, Önemli Günler, Kurum Adları, Gazete ve Dergi Adları, Kanal Adları, Hayvan Adları” başlıklarına ait özel ad kitapta yoktur. Özel adların kitap sayfa sayısına oranı \%19'dur.

\section{Türkçe ve Türk kültürü 2}

Kitap 216 sayfadan oluşmaktadır. Kitabın başında iki kıta olarak İstiklal Marşı yer almaktadır.

Tablo 33. Kişi adları

$\begin{array}{lllllll}\text { Ajda } & \text { Ali } & \text { Anıl } & \text { Ayça } & \text { Aylin } & \text { Bilal } & \text { Canan } \\ \text { Cem } & \text { Cemil } & \text { Çetin } & \text { Demet } & \text { Ece } & \text { Eda } & \text { Efe } \\ \text { Ekon } & \text { Elika } & \text { Emine } & \text { Eray } & \text { Fatih } & \text { Fatma } & \text { Filiz } \\ \text { Gizem } & \text { Gülay } & \text { Güneş } & \text { Halit } & \text { Hatice } & \text { Hüseyin } & \text { Irmak } \\ \text { İlke } & \text { Jale } & \text { Kemal } & \text { Kenan } & \text { Leman } & \text { Mete } & \text { Mine } \\ \text { Nikol } & \text { Nil } & \text { Numan } & \text { Okan } & \text { Oya } & \text { Ömer } & \text { Önel } \\ \text { Öykü } & \text { Parıltı } & \text { Pelin } & \text { Pınar } & \text { Rana } & \text { Selim } & \text { Sema } \\ \text { Sevgi } & \text { Şener } & \text { Talat } & \text { Tülin } & \text { Umut } & \text { Utku } & \text { Ülker } \\ \text { Ülkü } & \text { Veli } & \text { Veysel } & \text { Volkan } & \text { Ziya } & & \end{array}$

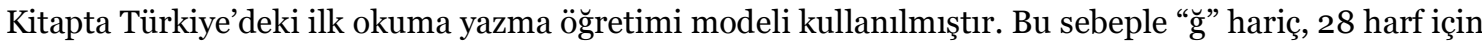
özel adlara yer verilmiştir. 61 özel addan 3 tanesi yabancı özel addır.

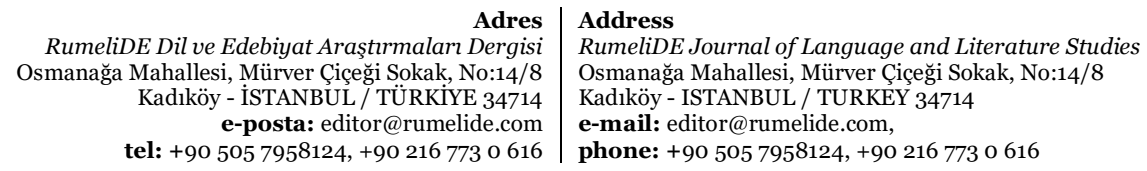


Tablo 34. Ülke adları
Almanya
Belçika
Türkiye

Kitapta 3 ülke adı geçmektedir. İki ülke Türklerin nüfusunun yoğun olduğu ülkelerdir.

Tablo 35. Şehir adları

$\begin{array}{lllll}\text { Ankara } & \text { Bolu } & \text { Bremen } & \text { Çankırı } & \text { Diyarbakır } \\ \text { Gaziantep } & \text { İstanbul } & \text { İzmir } & \text { Kars } & \text { Kayseri } \\ \text { Konya } & \text { Samsun } & \text { Sivas } & \text { Tokat } & \text { Van }\end{array}$

Kitapta 15 şehir adı geçmektedir. Sadece 1 şehir farklı bir ülkededir. Bunun dışında “Ankara”, “İstanbul”, "İzmir" gibi üç büyük şehir kitapta yer almaktadır.

Tablo 36. Milliyet ve mensubiyet adları

Alman

Türk

Kitapta 2 milliyet adı geçmektedir. Almanya ülke adı olarak geçtiği gibi milliyet olarak da kitapta yer almıştır.

Tablo 37. Dil adları

Türkçe

Kitapta yer alan tek dil adı Türkçedir.

Tablo. 39. Meşhur kişiler

Atatürk

Kitapta tek meşhur ad “Atatürk”tür.

Tablo 40. Mekân adları
Anitkabir
Canik Oyuncak Müzesi
İstanbul Oyuncak Müzesi

Kitapta 3 mekân adı geçmektedir. Bunlardan biri Anıtkabir'dir.

Tablo 41. Bayram adları

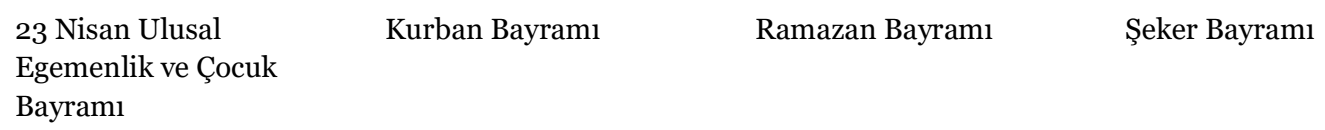

Kitapta 1 resmî bayram ve iki dini bayram adı toplam 4 bayram geçmektedir. Ramazan Bayramı kitapta şeker bayramı olarak da verilmiştir.

Tablo 42. Önemli günler

Ramazan

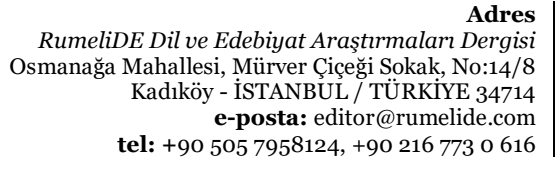

Adres

RumeliDE Journal of Language and Literature Studies

Osmanağa Mahallesi, Mürver Çiçeği Sokak, No:14/8

Kadıköy - ISTANBUL / TURKEY 34714

e-mail: editor@rumelide.com,

phone: +90 5057958124 , +90 2167730616 
Kitapta önemli gün olarak Ramazan ayının adı yer almaktadır.

Tablo 43. Eser ve kahraman adları

Hacivat Karagöz

Keloğlan

Kitapta 2 kahraman yer almaktadır. Karagöz ve Hacivat her oyunda birlikte geçtikleri için tek kahraman olarak sayılmıştır. İki kahraman da Türk kültürünün, edebiyatının önemli simgeleridir.

Tablo 44. Hayvan adları

Masal Şapşik ( maymun) Şaşkın

Kitapta 3 hayvan adı geçmektedir. İsimler yaygın kullanılan hayvan özel adları olmasa da çocukların hayvanlara ad koyarken farklı isimler de seçebileceğine bir örnek teşkil etmektedir.

Türkçe ve Türk Kültürü-2 kitabında 96 özel ad geçmektedir. Özel adların \%64'ü şahıs adı, \%16'sı şehir adıdır. Diğer adların oranları birbirine yakındır. Kitapta 15 başlık maddesinden 11’i yer almaktadır. "Dinle İlgili özel Adlar, Kurum Adları, Gazete ve Dergi Adları, Kanal Adları" başlıklarına ait özel ad kitapta yoktur. Özel adların kitap sayfa sayısına oranı \%44’tür.

\section{Türkçe ve Türk kültürüi 3}

Kitap 154 sayfadan oluşmaktadır. Kitabın başında İstiklal Marşı 2 Kıta olarak yer almaktadır. Kitabın başlangıcından itibaren üstteki diğer kitaplardan daha yoğun bir kültür aktarımı dikkat çekmektedir. Kitapta Türkiye vurgusu sürekli yapılmış, Türk bayrağı, Türkiye haritası ve boyama etkinliği görseli oldukça sık kullanılmış. Bayram ziyareti (ancak hangi bayramlar olduğu belirtilmemiş), akrabalık ilişkileri verilmiş, bayramlar ve kutlamalar bölümünde okullardaki süslemeler kullanılmış ve kitapta farklı bir görüntü oluşturmuş lokma dağıtma geleneği, inanç özgürlüğüne vurgu cümle sıralama ile verilmiş. Diğer kitaplardan bu kitaba geçişte kültür aktarımının ifadesinde yoğunluk olarak bariz bir farklılık görülmüştür. Bu kitaptan sonra da kültür aktarımı yoğun olarak devam etmektedir.

Tablo 44. Kişi adları

$\begin{array}{llllll}\text { Ahmet } & \text { Ali } & \text { Alice } & \text { Ayşe } & \text { Elif } & \text { Ezgi } \\ \text { Fadime } & \text { Hans } & \text { Hera } & \text { Leander } & \text { Mehmet } & \text { Mustafa } \\ \text { Nesrin } & \text { Sevgi } & \text { Zeynep } & & & \end{array}$

Kitapta 15 özel şahıs ismi geçmektedir. 4’ü yabancı Özel adlardır. Diğger adlar Türkiye'de yaygın kullanılan adlardan seçilmiştir.

Tablo 45. Ülke adları

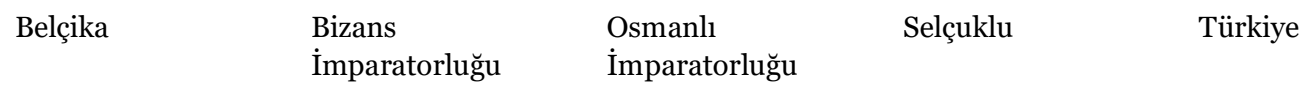

Kitapta 5 ülke adı geçmektedir. Ancak kitapta 3 ülke adı vardır, diyebiliriz. Selçuklu, Osmanlı ve Türkiye aynı ülkeyi, devleti ifade etmektedir. Türk çocuklarının tarihte Türk devletlerini tanımaları, köklerini bilmeleri açısından Osmanlı ve Selçuklu adının kitaplarda yer alması kültür tarihimiz açısından önem arz etmektedir.

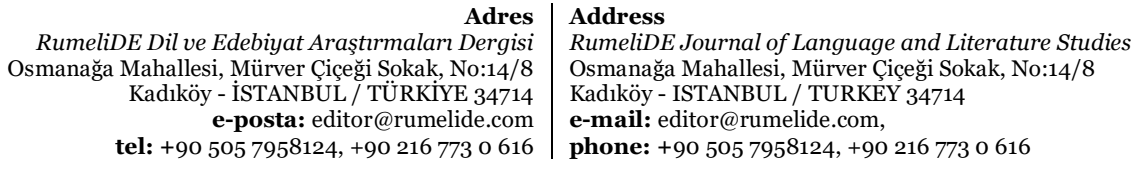


Tablo 46. Şehir adları

$\begin{array}{lllll}\text { Ankara } & \text { Bursa } & \text { Çorum } & \text { Hatay } & \text { İstanbul } \\ \text { Kırşehir } & \text { Münih } & \text { Rize } & \text { Samsun } & \text { Yozgat }\end{array}$

Kitapta 10 şehir ismi yer almaktadır. 1 tanesi yabancı şehir olmakla birlikte kitapta İstanbul ve Ankara adı geçmektedir. Samsun Atatürk’ün Samsun'a çıkışıyla ilişkilendirilerek verilmiştir.

Tablo 47. Milliyet adları
Alman
Fransiz
Iraklı
Türk

Kitapta 4 milliyet adı geçmektedir. Diğer kitaplardan farklı olarak Iraklı ifadesi burada yer almaktadır. Türk ismi de kitapta geçmektedir.

Tablo 48. Dinle ilgili özel isimler

İslam

Kitapta dinle ilgili tek ad olarak “İslam” kelimesi geçmektedir.

Tablo 49. Meşhur kişiler

$\begin{array}{llll}\text { Abbas Çınar } & \text { Atatürk } & \text { Bestami Yazgan } & \text { Deniz Karakurt } \\ \text { Eren Sarı } & \text { Fatih Sultan Mehmet } & \text { Geyikli Baba } & \text { H. Kağan Keskin } \\ \text { Hadi Besleyici } & \text { Hasan Latif Sarı̈̈̈ce } & \text { Kanuni Sultan Süleyman } & \text { Mehmet Necati Öngay } \\ \text { Mustafa Kemal Atatürk } & \text { Necdet Neydim } & \text { Orhan Gazi } & \text { Süleyman Bulut }\end{array}$

Kitapta 16 meşhur isim anılmaktadır. Atatürk ve Mustafa Kemal Atatürk kitapta uzun ve kısa olarak yer almaktadır. Tarihimiz için önemli üç büyük devlet adamı "Fatih, Kanuni ve Orhan Gazi” de kitapta adı geçen Türk büyüklerindendir. Geyikli Baba ismi de Türk kültür tarihinin bir motif ismi olarak kitapta zikredilmiştir. Diğer isimler kitapta metinleri bulunan yazarlardır.

Tablo 5o. Mekân adları

$\begin{array}{lllll}\text { Akdeniz } & \text { Anadolu } & \text { Anıtkabir } & \text { Asya Kıtası } & \text { Avrupa Kıtası } \\ \text { Ayasofya } & \text { Balkanlar } & \text { Batı Anadolu } & \text { Boğaziçi } & \text { Emirdağ } \\ \begin{array}{l}\text { Güney Doğu } \\ \text { Anadolu } \\ \text { Orta Asya }\end{array} & \text { İstanbul Boğazı } & \text { Karadeniz } & \text { Kavaklı Cami } & \text { Kız Kulesi } \\ & \begin{array}{l}\text { Sultanahmet } \\ \text { Camisi (Mavi }\end{array} & \text { Topkapı Sarayı } & \text { Yavuz Köyü } & \\ & \text { Camii) } & & & \end{array}$

Kitapta 19 mekân adı geçmektedir. Kıta isimleri, Türkiye'nin bölgeleri bu isimlerden bazılarıdır. Kitapta Anıtkabir ismi geçmektedir. Ayasofya, Sultan Ahmet, Kız Kulesi, Topkapı Sarayı, İstanbul Boğazı Türkler için tarihi öneme sahip önemli kültür taşlarıdır. Eserde bu mekânların bulunması önem arz etmektedir.

Tablo 51. Bayram adları

19 Mayıs Atatürk’ü anma ve Gençlik Spor Bayramı
23 Nisan Ulusal Egemelik ve Çocuk Bayramı
30 Ağustos Zafer
Bayramı
29 Ekim Cumhuriyet

Bayramı

\footnotetext{
Adres | Address

RumeliDE Dil ve Edebiyat Araştırmaları Dergisi Osmanağa Mahallesi, Mürver Çiçeği Sokak, No:14/8 Kadıköy - ÍSTANBUL / TÜRKIYE 34714 e-posta: editor@rumelide.com

RumeliDE Journal of Language and Literature Studies Osmanağa Mahallesi, Mürver Çiçeği Sokak, No:14/8 Kadıköy - ISTANBUL / TURKEY 34714

e-mail: editor@rumelide.com tel: +90 505 7958124, +90 216773 o 616 phone: +90 505 7958124, +90 2167730616
} 
Kitapta 4 resmî bayram adı geçmektedir. Dinî bayram adları kitapta yer almamaktadır. Kültür kitabının içinde dinî bayramlara da yer verilmesi gerektiği düşünülmektedir.

Tablo 52. Önemli günler

Kurtuluş Savaşı

Ramazan

Kitapta 2 önemli gün adı geçmektedir. Kurtuluş Savaşı Türkiye Cumhuriyeti’nin kuruluşunda temel olan mücadelenin adıdır. Bu ismin Türk kültürü adıyla anılan kitaplarda bulunması önem taşımaktadır. Ramazan Bayramı kitapta geçmese de ay adı olarak verilmiştir.

Tablo 53. Eser ve kahraman adları
Boğaç Han
Dede Korkut
Türk Halk Müziği

Kitapta 2 kahraman ve 1 eser adı geçmektedir. Türk Halk Edebiyatı'nın simge ismi Dede Korkut ve Boğaç Han'ın kitapta adının geçmesi, Türk çocuklarının bu iki isim hakkında bir farkındalık kazanmalarını sağlayacaktır. Türk kültürünün bir unsuru da Türk müziğidir. Üstteki diğer kitaplardan farklı olarak burada müzikle ilgili bir özel adın verilmesi de önemlidir.

Tablo 54. Kurum adları

\begin{tabular}{|c|c|c|c|c|}
\hline Anıtkabir Müzesi & Bandırma Vapuru & Türk Kızılayı & $\begin{array}{l}\text { Türkiye Büyük } \\
\text { Millet Meclisi }\end{array}$ & $\begin{array}{l}\text { Türkiye } \\
\text { Cumhuriyeti } \\
\text { Cumhurbaşkanlığı }\end{array}$ \\
\hline
\end{tabular}

Kurum adı olarak 5 yer adı geçmektedir. Anıtkabir hem müzesi ile hem de sadece "Anıtkabir" olarak kitapta yer almıştır. Özellikle Meclis ve Cumhurbaşkanlığına ait kurumların verilmesi Türkiye'nin yönetim şeklini de çocuklara öğretmek açısından önemlidir. Bandırma Vapuru bir kurum olmasa da müze olarak ziyaret edildiği için kurumlar arasında sınıflandırılmıştır.

Türkçe ve Türk Kültürü-3 kitabında 84 özel ad geçmektedir.\%23’ü mekân adları, \%19’u meşhur kişiler, \%18’ini şahıs isimleri, \%12'si şehir adlarıdır. Diğer özel adların dağılımı \%10'unun altındadır. 15 başlıktan 11'i kitapta vardır. "Dil Adı, Gazete ve Dergi Adları, Kanal Adları, Hayvan Adları" kitabın içinde yer almayan özel ad başlıklarıdır. Kitabın içinde "Türkçe” dil adı hiç geçmemektedir. Kitapta geçen özel adların sayfa sayısına oranı \% 55 ’tir.

\section{Türkçe ve Türk kültürü 4}

Kitap 138 sayfadan oluşmaktadır. Kitapta İstiklal Marşı'nın 10 kıtası ve Gençliğe Hitabe bulunmaktadır.

Tablo 55. Kişi adları

$\begin{array}{llllll}\text { Ahed } & \text { Ahmet } & \text { Ali } & \text { Ayşe } & \text { Ceren } & \text { Çnar } \\ \text { Doğan } & \text { Ece } & \text { Efe } & \text { Elif } & \text { Gezgin Çelebi } & \text { Gözde } \\ \text { Hasan } & \text { Hayri } & \text { Kamil } & \text { Kerem } & \text { Kubilay } & \text { Kurtis } \\ \text { Leyla } & \text { Masal } & \text { Mehmet } & \text { Murat } & \text { Saffet } & \text { Sinem }\end{array}$

Kitapta 24 şahıs adı geçmektedir. Kullanılan isimlerden Ahed ve Kurtis'in yabancı isim olarak geçmektedir. Diğer isimlerde yaygın olarak kullanılan Türk isimleridir.

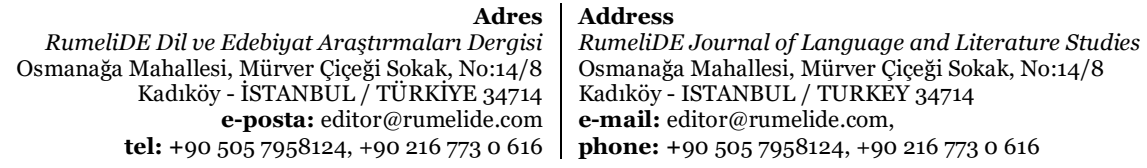


Tablo 56. Ülke adları

$\begin{array}{lllll}\text { Afganistan } & \text { Almanya } & \text { Amerika } & \text { Filipinler } & \text { Fransa } \\ \text { Hindistan } & \text { İran } & \text { İsviçre } & \text { İtalya } & \text { Japonya } \\ \text { Osmanlı } & \text { Selçuklu } & \text { Tayland } & \text { Tibet } & \text { Türkiye }\end{array}$

Kitapta 13 ülke adı geçmektedir. Selçuklu-Osmanlı-Türkiye yukarıdaki gibi tek ülke olarak sayılmıştır. Ülkelerin farklı kıtalardan seçilmesi çeşitlilik katmıştır.

Tablo 57. Şehir adları

$\begin{array}{lllllll}\text { Adiyaman } & \text { Afyon } & \text { Aksaray } & \text { Ankara } & \text { Antalya } & \text { Belh } & \text { Berlin } \\ \text { Bursa } & \text { Çanakkale } & \text { Denizli } & \text { Erzurum } & \text { Giresun } & \text { İstanbul } & \text { Karabük } \\ \text { Kayseri } & \text { Kocaeli } & \text { Muğla } & \text { Nevşehir } & \text { Nişabur } & \text { Zürih } & \end{array}$

Kitapta metinlerin içinde 20 şehir geçmekle birlikte bir hava durumu haritası ile Türkiye'nin tüm şehirleri verilmiştir. Nişabur ve Buhara gibi Türk tarihinin önemli şehirlerinin adı da kitapta bulunmaktadır. Kitapta adı geçen Berlin ve Zürih de yurt dışında Türklerin yaşadığı şehirlerdendir.

Tablo 58. Milliyet adları

$\begin{array}{lll}\text { Alman } & \text { Amerikalı } & \text { Arap } \\ \text { Çinli } & \text { Eskimo } & \text { Hint } \\ \text { İskoç } & \text { Meksikalı } & \text { Türk }\end{array}$

Kitapta 9 milliyet adı geçmektedir. "Türk" kelimesi metinlerde zikredilmektedir. Farklı kıtalara ait milliyet adlarının geçmesi diğer kitaplara göre bir farklılık arz etmektedir.

Tablo 59. Dil adları
Arapça
Farsça
Türkçe

Kitapta 3 dil adı geçmektedir. Bu diller, Osmanlı Türkçesini oluşturan diller olması yanında Türkçe ve Türk Kültürü kitaplarının okutulduğu coğrafyalarda konuşulan dil isimleridir.

Tablo 59. Dinle ilgili özel adlar
Allah
İslam
İslamiyet

Dinle ilgili 3 özel ad kitapta yer almaktadır. İkinci kez bu kitapta İslam ve Allah adı, ilk kez İslamiyet adı geçmektedir.

Tablo 6o. Meşhur kişiler

\begin{tabular}{|c|c|c|c|c|c|}
\hline I.Ahmet & Altan Özyürek & Âşık Paşa & Atatürk & II.Bâyezid & Bayram Baş \\
\hline $\begin{array}{l}\text { Berna } \\
\text { Türkdoğan }\end{array}$ & Deniz Özen & Derya Duman & Derya Örs & Doğukan İşler & Fethi Bolayır \\
\hline Gazi Mustafa & H. Kübra & Hacı Bayram & İmparator & Mevlana & Nur içözü \\
\hline Kemal & Tongar & Veli & Konstantin & & \\
\hline $\begin{array}{l}\text { Sultan } \\
\text { Abdülmecid }\end{array}$ & Taptuk Emre & Yunus Emre & Yüksel Ünsal & & \\
\hline
\end{tabular}

\footnotetext{
Adres | Address

RumeliDE Dil ve Edebiyat Araştırmaları Dergisi Osmanağa Mahallesi, Mürver Çiçeği Sokak, No:14/8 Kadıköy - İSTANBUL / TÜRKIYE 34714 e-posta: editor@rumelide.com

RumeliDE Journal of Language and Literature Studies Osmanağa Mahallesi, Mürver Çiçeği Sokak, No:14/8 Kadıköy - ISTANBUL / TURKEY 34714

e-mail: editor@rumelide.com tel: +90 505 7958124, +90 216773 o 616 phone: +90 505 7958124, +90 2167730616
} 
Kitapta 23 meşhur isim geçmektedir. "Atatürk” ve "Gazi Mustafa Kemal Paşa” ayrı ayrı kullanılmıştır. Osmanlı padişahlarından üçünün adına yer verilmiştir. Yunus Emre, Taptuk Emre, Hacı Bayram Veli, Mevlana gibi kültürümüzün, edebiyat ve tarihimizin önemli isimleri de kitapta bulunmaktadır. Diğer isimler kitapta şiir ve yazıları bulunan isimlerdir

Tablo 61. Mekân adları

\begin{tabular}{|c|c|c|c|c|c|c|c|}
\hline Apollon & Anadolu & $\begin{array}{l}\text { Atatürk } \\
\text { Barajı }\end{array}$ & $\begin{array}{l}\text { Atmeydanı } \\
\text { Caddesi }\end{array}$ & Avanos & Avrupa & $\begin{array}{l}\text { Beşiktaş } \\
\text { İskelesi }\end{array}$ & $\begin{array}{l}\text { Cacabey } \\
\text { Medresesi }\end{array}$ \\
\hline Çemberlitaş & Dikilitaş & $\begin{array}{l}\text { Divanyolu } \\
\text { Caddesi }\end{array}$ & $\begin{array}{l}\text { Dolmabahçe } \\
\text { Sarayı }\end{array}$ & Ege & $\begin{array}{l}\text { Eminönü } \\
\text { İskelesi }\end{array}$ & $\begin{array}{l}\text { Firat } \\
\text { nehri }\end{array}$ & $\begin{array}{l}\text { Firüzağa } \\
\text { Camisi }\end{array}$ \\
\hline Galata & Güney Ege & Hacı & Haydarpaşa & Hidırlık & Hierapolis & Ihlara & İç \\
\hline Kulesi & & $\begin{array}{l}\text { Bayram Veli } \\
\text { Camisi }\end{array}$ & Garı & Tepesi & $\begin{array}{l}\text { Antik } \\
\text { Kenti }\end{array}$ & Vadisi & Anadolu \\
\hline $\begin{array}{l}\text { Kabataş } \\
\text { İskelesi }\end{array}$ & Kapadokya & Kartepe & Kız Kulesi & $\begin{array}{l}\text { Kleopatra } \\
\text { Havuzu }\end{array}$ & Kocatepe & $\begin{array}{l}\text { Koza } \\
\text { Han }\end{array}$ & Kuzey Ege \\
\hline Marmara & $\begin{array}{l}\text { Mevlana } \\
\text { Müzesi }\end{array}$ & $\begin{array}{l}\text { Nemrut } \\
\text { Dağ }\end{array}$ & $\begin{array}{l}\text { Orta ve } \\
\text { Doğu } \\
\text { Karadeniz }\end{array}$ & Palandöken & Pamukkale & $\begin{array}{l}\text { Peyhane } \\
\text { Caddesi }\end{array}$ & $\begin{array}{l}\text { Saat } \\
\text { Kulesi }\end{array}$ \\
\hline Safranbolu & Salacak & $\begin{array}{l}\text { Sultanahmet } \\
\text { Camisi } \\
\text { (Mavi Cami) }\end{array}$ & Şuhut & Uludağ & $\begin{array}{l}\text { Üsküdar } \\
\text { İskelesi }\end{array}$ & & \\
\hline
\end{tabular}

Kitapta 46 mekân adı geçmektedir. Türkiye’nin bölgelerine verilen adlar, bazı yeryüzü şekilleri burada yer alan özel isimlerdendir. Kız Kulesi, Sultaahmet Camii, Dikilitaş, Dolmabahçe sarayı gibi coğrafî ve tarihî işaretler de kitapta bulunmaktadır. Mekânların hepsi Türkiye’dedir.

Tablo 62. Bayram adları

$\begin{array}{llll}\text { 19 Mayıs Gençlik ve Spor } & \text { 23 Nisan Ulusal } & \text { 30 Ağustos Zafer } & \text { 29 Ekim Cumhuriyet } \\ \text { Bayramı } & \text { Egemenlik ve Çocuk } & \text { Bayramı } & \text { Bayramı } \\ & \text { Bayramı } & \end{array}$

Kitapta 4 bayram adı geçmektedir. Dördü de resmi bayramdır. Dini bayramların adları kitapta yer almamaktadır.

Tablo 63. Eser ve kahraman adı

Garibname Gençlik Marşı İstiklal Marşı $\quad$ Mesnevi $\quad$ Rafadan Tayfa

Kitapta eser ve kahraman adı olarak 5 özel ad geçmektedir. İstiklal Marşı milli sembolümüz olarak kitap içindeki metinlerde de yer almaktadır.

Tablo 64. Kurum adları

TBMM Türkiye Büyük Millet Meclisi Unesco

Kitapta 2 kurum adı vardır. TBMM hem kısaltma olarak hem de tam olarak kitapta yer alır.

Tablo 65. Kanal adı

TRT Çocuk

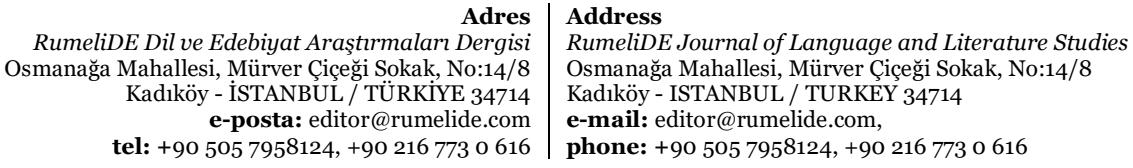

tel: +90 505 7958124, +90 2167730616 phone: +90 505 7958124, +90 2167730616 
Kitapta geçen tek kanal adı TRT Çocuk 'tur. Kitaplar çocukların yaş seviyeleri gözetilerek yazıldığı için sadece bu kanalın verildiği düşünülmektedir.

Türkçe ve Türk Kültürü-4 kitabında 154 özel ad geçmektedir. Bu özel adların \%3o’u mekân adları, \%16’sı kişi adları, \%15’i meşhur kişiler, \%13’ü şehir adıdır. Diğer oranlara \%10’unun altındadır. 15 ana başlıktan 12'sine ait özel adlar kitapta mevcuttur. "Önemli Günler, Hayvan Adları, Gazete ve Dergi Adları" kitapta yer almayan başlık maddeleridir. Özel adların sayfa sayısına oranı \%112’dir.

\section{Türkçe ve Türk kültürü 5}

Kitap 151 sayfadan oluşmaktadır. Kitap İstiklal Marşı’nın 10 kıtası ve Gençliğe Hitabe ile başlamaktadır.

Tablo 66. Kişi adları

$\begin{array}{lllll}\text { Aksu } & \text { Ali } & \text { Batuhan } & \text { Begüm } & \text { Hüseyin } \\ \text { Luka } & \text { Mia } & \text { Murat } & \text { Nermin } & \text { Neşe }\end{array}$

Kitapta şahıslara özel 10 isim geçmektedir. Bunlardan "Aksu” soyadı olarak kullanılmıştır. 2 isim yabancıların kullandığı özel adlardır. Diğer isimler yaygın ve klasik olarak kullanılan isimler ve Begüm, Batuhan gibi diğerlerine oranla biraz daha az tercih edilen isimlerdir. CNN Türk'ün(2021) TÜIKK istatistiklerine göre yaptığı haberde, Türkiye'de o-17 yaş grubundaki çocukların isimlerine bakıldığında ise Yusuf, Mehmet, Mustafa, Ahmet ve Furkan isimlerinin başı çektiği görülmektedir. Bu geleneksel isimlerin yanında Ömer, Berat, Enes ve Muhammed gibi isimler en popüler 10 isim listesinde yer almaktadır. Son 17 yılda Türkiye'de istikrarlı biçimde en çok tercih edilen kız çocuk isimleri Zeynep ve Elif olurken, ailelerin kız çocuklarına geleneksel isim verme eğiliminin erkek çocuklarından daha düşük olması dikkati çekmektedir.

Tablo 67. Ülke adları

\begin{tabular}{|c|c|c|c|c|c|}
\hline Almanya & Amerika & Arjantin & Avusturya & Azerbaycan & Belçika \\
\hline Çin & Danimarka & Fransa & $\begin{array}{l}\text { Hitit } \\
\text { İmparatorluğu }\end{array}$ & İngiltere & İran \\
\hline İspanya & İtalya & Japonya & Japonya & Kanada & Meksika \\
\hline Misir & Osmanlı & Rusya & Türkiye & & \\
\hline
\end{tabular}

Kitapta 22 ülke adı yer almaktadır. Osmanlı ve Türkiye tek ülke olarak ifade edilmiştir. Hitit İmparatorluğu dışında diğer ülkeler günümüzde varlığını sürdüren ülkelerdir. Ülkeler genel olarak Türk nüfusun bulunduğu ülkelerdir.

Tablo 68. Şehir adları

$\begin{array}{lllll}\text { Ankara } & \text { Artvin } & \text { Balıkesir } & \text { Berlin } & \text { Brüksel } \\ \text { Bursa } & \text { Çanakkale } & \text { Çorum } & \text { Erzincan } & \text { Erzurum } \\ \text { İstanbul } & \text { İzmir } & \text { Kars } & \text { Malatya } & \text { Muğla } \\ \text { Samsun } & \text { Şanllurfa } & \text { Uşak } & \text { Viyana } & \end{array}$

Kitapta 19 şehir adı geçmektedir. Farklı ülkelerde yer alan iki şehir vardır. Kitapta geçen iller Türkiye'nin farklı bölgelerinde yer alan illerdir. Bu çeşitlilik önem göstermektedir. Ayrıca metinlerin içinde yer alan illerin haricinde kitapta bir Türkiye haritası da bulunmaktadır.

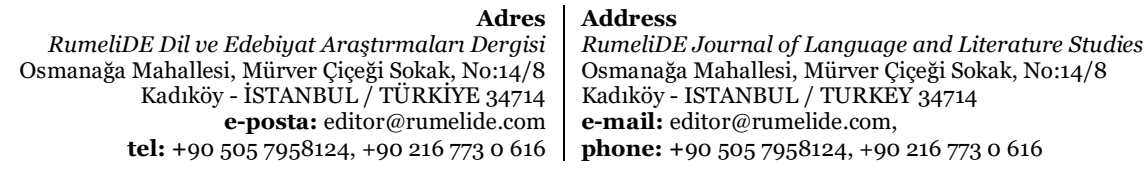


Tablo 69. Milliyet adları

Akhalılar Alman Avrupalı Avusturyalı Fransız İtalyan

Kitapta 7 milliyet adı geçmektedir. Bunlardan biri tarihte Yunan halkı için kullanılan Akhalı ismidir. Türk ismi kitapta geçmektedir. Bunun dışındaki milliyetler yukarıda verilen ülkelerden bazılarına ait milliyet isimleridir. Kitapta hem ülkenin hem de aynı ülkeye ait milliyet adının verilmesi öğrencilerin dile ait isimlerin nasıl iki türde nasıl kullanıldığını görmeleri açısından önemlidir.

Tablo 7o. Dil adları

\section{Türkçe}

Kitapta geçen tek dil adı Türkçedir.

Tablo 71. Dinle ilgili özel adlar
Allah
Hz. Muhammed
Müslüman
Nuh Tufanı

Dinle ilgili kullanılan 4 özel isim vardır. Bunlar İslamiyet’e mensup bir şahsın bilmesi gereken ilk özel isimlerdir: Allah, Hz. Muhammed, Müslüman. Ayrıca Nuh Tufanı da tüm dinler tarafından ortak kabul edilen tarihî bir olaydır.

Tablo 72. Meşhur kişiler

\begin{tabular}{|c|c|c|c|c|}
\hline Ahmet Kutsi Tecer & Atatürk & Bahaeddin & Cemal Oğuz Öcal & $\begin{array}{l}\text { Edmondo de } \\
\text { Amicis }\end{array}$ \\
\hline Ertuğrul Düzdağ & Franz Carl Endres & Franz Custers & Fritz Neumark & $\begin{array}{l}\text { Ghiselin de } \\
\text { Busbecg / }\end{array}$ \\
\hline Gökhan Duman & Hacı Bektaş Veli & Hamdullah Suphi & Kudret Emiroğlu & Ludwig Ross \\
\hline Mehmet Akif Ersoy & $\begin{array}{l}\text { Mevlana Celaleddin } \\
\text { Rumi }\end{array}$ & $\begin{array}{l}\text { Mustafa Kemal } \\
\text { Atatürk }\end{array}$ & Orhan Okay & Pretextat Lecomte \\
\hline Şeref Akgün & Tahsin Saraç & Uzay Sezen & $\begin{array}{l}\text { Wolfgang Amadeus } \\
\text { Mozart }\end{array}$ & \\
\hline
\end{tabular}

Kitapta 24 meşhur isim yer almaktadır. 10 isim yabancı kişilerden oluşmaktadır. Atatürk ve Mustafa Kemal Atatürk ismi ayrı ayrı verilmektedir. İstiklal Marşı'mızın şairi Mehmet Akif Ersoy’un adı geçmektedir. Hacı Bektaş Veli ve Mevlana Celaleddin Rumi de Türk kültürünün önemli isimleridir, kitapta isimleri geçmektedir.

Tablo 73. Mekân adları

$\begin{array}{llllllll}\text { Anadolu } & \text { Anıtkabir } & \begin{array}{l}\text { Ani } \\ \text { harabeleri }\end{array} & \text { Asılı Taşlar } & \text { Asya } & \text { Avrupa } & \text { Avusturalya } & \text { Çin Seddi } \\ \begin{array}{l}\text { Divriği Ulu } \\ \text { cami }\end{array} & \text { Dolmabahçe } & \text { Ege } & \text { Göbeklitepe } & \text { Hattuşa } & \text { Kâbe } & \text { Karadeniz } & \begin{array}{l}\text { Kazdağı } \\ \text { Milli } \\ \text { Parkı }\end{array} \\ \text { Konzerthaus } & \begin{array}{l}\text { Misır } \\ \text { Piramitleri }\end{array} & \text { Orta Asya } & \begin{array}{l}\text { Taceddin } \\ \text { Dergâhı } \\ \text { Müzesi }\end{array} & \begin{array}{l}\text { Truva } \\ \text { Antik } \\ \text { Kenti }\end{array} & \text { Üsküdar } & & \\ & & & & & & \end{array}$

Kitapta 22 mekân adı geçmektedir. “Anıtkabir” ismi geçmektedir. Türkiye’nin bölgelerinden ikisi verilmiştir: Karadeniz ve Ege. 4 mekân Türkiye dışındaki yerlerdir. Bunlardan biri de Müslümanlar için

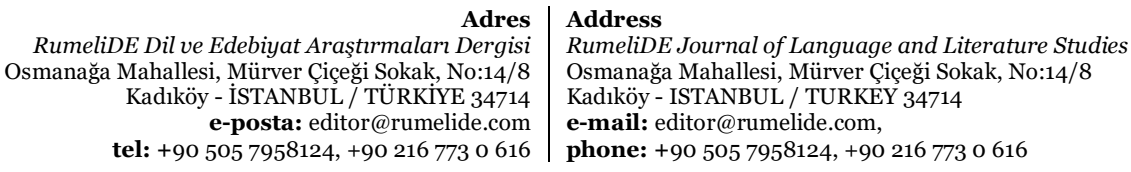


kutsal mekân Kâbe’ dir. Göbeklitepe, Dolmabahçe, Ani Harabeleri verilen mekânlar içinde önemli tarihi yerlerdir.

Tablo 74. Bayram adları

Zafer Bayramı

19 Mayıs Gençlik ve Spor Cumhuriyet Bayramı Bayramı
23 Nisan Ulusal Egemenlik ve Çocuk Bayramı

Kitapta 4 bayram adı geçmektedir. Dördü de resmî bayramdır. Dinî bayramlar kitapta ad olarak geçmemektedir.

Tablo 75. Önemli günler

Milli Mücadele

15 Temmuz Demokrasi ve Millî Birlik Günü

Kitapta iki önemli gün adı verilmiştir. Milli Mücadele, Türkiye Cumhuriyetinnin kuruluşunun mücadelesidir. 15 Temmuz da Türk milletinin, tarihin her döneminde vatanı için canını, göz kırpmadan feda edebileceğinin önemli bir göstergesidir. Milli bilincin oluşmasında bu günlerin anılmasının önemli bir yeri vardır.

Tablo 76. Eser ve kahraman adları

\begin{tabular}{|c|c|c|c|c|c|}
\hline Çocuk Kalbi & Define Adası & $\begin{array}{l}\text { İki Yıl Okul } \\
\text { Tatili }\end{array}$ & İstiklal Marşı & Kibritçi Kız & $\begin{array}{l}\text { Küçük Kara } \\
\text { Balık }\end{array}$ \\
\hline Martı & Mehter marşı & Mesnevi & Safahat & Şeker Portakalı & \\
\hline
\end{tabular}

Kitapta 11 eser adı geçmektedir. Bu eserlerden 7'si "Dünya Çocuk Klasikleri” arasında yer alan hikâye kitaplarıdır. İstiklal Marşı, Safahat, Mesnevi, Mehter Marşı ise bizim edebiyatımıza ait eserlerdir. Dünya çocuk edebiyatından 7 örneğin yer aldığı bir kitapta, Türk yazarların yazdığı birkaç çocuk kitabının da eserler arasında anılması gerektiği düşünülmektedir.

Tablo 77. Kurum adları

$\begin{array}{llllll}\begin{array}{l}\text { Emniyet Genel } \\ \text { Müdürlüğü }\end{array} & \begin{array}{l}\text { Gülhane } \\ \text { Hastanesi }\end{array} & \begin{array}{l}\text { Kültür ve } \\ \text { Turizm } \\ \text { Bakanlığı }\end{array} & \begin{array}{l}\text { Millî Eğitim } \\ \text { Bakanlığı }\end{array} & \begin{array}{l}\text { Türkiye Büyük } \\ \text { Millet Meclisi }\end{array} & \begin{array}{l}\text { Türkiye } \\ \text { Cumhuriyeti }\end{array} \\ \begin{array}{l}\text { Türkiye Yazma } \\ \text { Eserler Kurumu } \\ \text { Başkanlığı }\end{array} & \begin{array}{l}\text { Uluslararası } \\ \text { Turna Koruma }\end{array} & \text { Unesco } & & & \\ \text { Vakfı } & & & \end{array}$

Kitapta 9 kurum adı geçmektedir. Bu kurum isimlerinin arasına "Türkiye Cumhuriyeti” de alınmıştır. Türkiye’nin önemli kurumları Meclis, Milli Eğitim, Kültür Bakanlı̆̆ kitapta yer almaktadır. Uluslararası Turna Koruma Vakfı da kitapta yer alarak nesli tükenmekte olan hayvanları korumak için farkındalık oluşturmaktadır.

Tablo 78. Kanal adları

Cnn Türk

Kitapta adı geçen tek kanal adı "CNN Türk”tür.

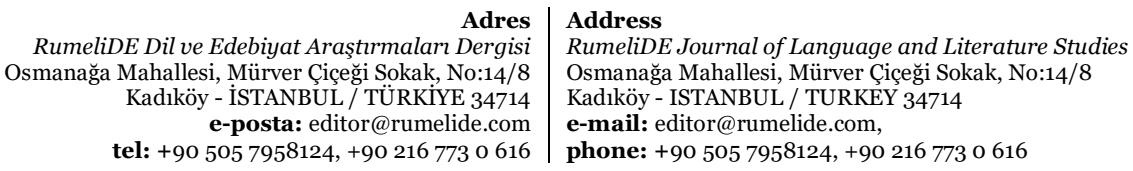


Türkçe ve Türk Kültürü-5 kitabında 135 özel ad geçmektedir. Bu adlardan \%17’si meşhur kişiler, \%17’si mekân adı, \%16'sı ülke adı, \%15’i şehir adıdır. Bu kitaptaki şahıs adları \%7'lik bir oranla diğer kitaplara göre daha az bir yer tutmaktadır. Diğer oranlar da \%10’un altındadır. 15 ana başlıktan 12'si kitapta vardır. "Gazete ve Dergi Adları, Hayvan Adları" başlıkları kitapta yer almamaktadır. Kitabın sayfa sayısına oranla özel adlar \%93 oranında kitapta yer almaktadır.

\section{Türkçe ve Türk kültürü 6}

Kitap 167 sayfadan oluşmaktadır. Gençliğe hitabe ve istiklal Marşı 10 kıta şeklinde kitapta yer almaktadır.

Tablo 79. Kişi adları

$\begin{array}{llllll}\text { Ahmet } & \text { Ali } & \text { Burcu } & \text { Bülent } & \text { Efe } & \text { Gül } \\ \text { Hasibe } & \text { Mehmet } & \text { Murat } & \text { Mustafa } & \text { Sevgi } & \end{array}$

Kitapta 11 özel isim geçmektedir. İsimler Türkiye'de yaygın olarak kullanılan kız ve erkek isimleridir.

Tablo 8o. Ülke adları

$\begin{array}{lllllll}\text { Almanya } & \begin{array}{l}\text { Anadolu } \\ \text { Selçuklu } \\ \text { Devleti }\end{array} & \begin{array}{l}\text { Asya Hun } \\ \text { Devleti }\end{array} & \begin{array}{l}\text { Avrupa Hun } \\ \text { Devleti }\end{array} & \begin{array}{l}\text { Büyük } \\ \text { Selçuklu } \\ \text { Devleti }\end{array} & \text { Franklar } & \text { Gazneliler } \\ \begin{array}{l}\text { Göktürk } \\ \begin{array}{l}\text { Devleti } \\ \text { Osmanlı }\end{array}\end{array} & \text { Oollanda } & \text { Kanada } & \text { Karahanlılar } & \text { Kayı Boyu } & \text { Libya } & \text { Orta Anadolu } \\ \text { Devleti } & & \text { Selçuklular } & \text { Surinam } & \text { Türkiye } & \begin{array}{l}\text { Uygur } \\ \text { Devleti }\end{array} & \text { Vizigotlar }\end{array}$

Kitapta ülke adı olarak 21 özel ad geçmektedir. Bunlardan bazıları Türklerin tarihte kurduğu devletlerin adıdır. Göktürk, Uygur, Hun, Gazneliler, Karahanlılar, Selçuklular; Kayı Boyu, Osmanlı Devleti verilerek Türklerin tarihte kurduğu devlet isimleri kitapta anılmıştır. Farklı ülkelere ait isimler ve tarihte yer alan farklı devletler de kitapta adı geçen özel isimlerdir.

Tablo 81. Şehir adları

$\begin{array}{lllllll}\text { Adana } & \text { Adıyaman } & \text { Afyonkarahisar } & \text { Aksaray } & \text { Ankara } & \text { Antalya } & \text { Artvin } \\ \text { Aydın } & \text { Bağdat } & \text { Balıkesir } & \text { Batman } & \text { Berlin } & \text { Bilecik } & \text { Bursa } \\ \text { Çanakkale } & \text { Çorum } & \text { Denizli } & \text { Diyarbakır } & \text { Edirne } & \text { Elazı̆ } & \text { Erzurum } \\ \text { Eskişehir } & \text { Gaziantep } & \text { Hamburg } & \text { Hatay } & \text { Isparta } & \text { Isparta } & \text { Isparta } \\ \text { İstanbul } & \text { Kahramanmaraş } & \text { Kars } & \text { Kayseri } & \text { Kirşehir } & \text { Konya } & \\ \text { Malatya } & \text { Manisa } & \text { Mardin } & \text { Mersin } & \text { Muğla } & \text { Nevşehir } & \text { Ordu } \\ \text { Ötüken } & \text { Rize } & \text { Samsun } & \text { Siirt } & \text { Sinop } & \text { Sivas } & \text { Şanlıurfa } \\ \text { Trabzon } & & \text { Tunceli } & \text { Van } & \text { Yozgat } & \text { Zonguldak } & \end{array}$

Kitapta Türkiye haritası verilmekle birlikte 53 şehir adı geçmektedir. Üçü 2'si Almanya'da 1’i Irak'ta olmak üzere iki yabancı şehir adı vardır. "Ötüken” adı da kitapta verilmiştir. Ötüken Türk ve Orta Asya tarihlerinde kutsal başkenttir.

Tablo 82. Milliyet adları

\begin{tabular}{|c|c|c|}
\hline Alman & Avusturyalı & Fransız \\
\hline & $\begin{array}{r}\text { Adres } \\
\text { RumeliDE Dil ve Edebiyat Araștrrmalar Dergisi } \\
\text { Osmanağa Mahallesi, Mürver Ciçĕgi Sokak, No:14/8 } \\
\text { Kadıköy - İSTANBUL/ TÜRKIYE } 34714 \\
\text { e-posta: editor@rumelide.com } \\
\text { tel: }+90 \text { 505 7958124, +90 } 2167730616\end{array}$ & $\begin{array}{l}\text { Address } \\
\text { RumeliDE Journal of Language and Literature Studies } \\
\text { Osmanağa Mahallesi, Mürver Cicceği Sokak, No:14/8 } \\
\text { Kadıköy - ISTANBUL / TURKEY } 34714 \\
\text { e-mail: editor@rumelide.com, } \\
\text { phone: +90 505 7958124, +90 } 216773 \text { o } 616\end{array}$ \\
\hline
\end{tabular}


Kitapta 6 milliyet adı geçmektedir. "Türk” kelimesi kitapta mevcuttur. Bunun dışında ülke adı olarak geçmeyen ülkeler milliyet adı olarak kitapta verilmiştir.

Tablo 83. Dil adları

Türkçe

Kitapta verilen tek dil adı "Türkçe”dir.

Tablo 84. Dinle ilgili özel adlar

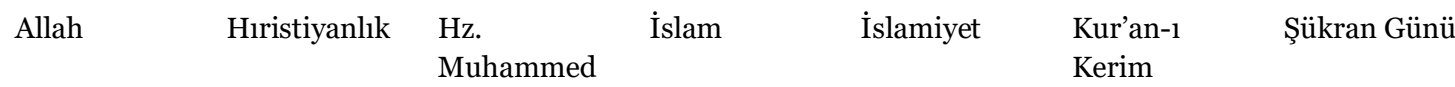

Kitapta dinle ilgili 7 özel ad verilmiştir. Kuran-ı Kerim ilk kez bu kitapta geçmektedir ve bu kitaptan itibaren diğer kitaplarda da verilmiştir. Ayrıca Hristiyanlık ve Şükran Günü de ilk kez bu kitapta verilmektedir.

Tablo 85. Meşhur kişiler

\begin{tabular}{|c|c|c|c|c|}
\hline $\begin{array}{l}\text { Abdülkerim Satuk } \\
\text { Buğra Han }\end{array}$ & $\begin{array}{l}\text { Ahmet Şerif } \\
\text { İzgören }\end{array}$ & Alp Tegin Han & Antonio Guterres & Asuman Karabulut \\
\hline Aşık Veysel & Atilla Han & Barış Manço & Bumin Kağan Han & Cahit Sitkı Tarancı \\
\hline $\begin{array}{l}\text { Cemile Burcu } \\
\text { Kartal }\end{array}$ & Cornelius Bischof & Emrah & Ertuğrul Bey & Fatih Sultan Mehmet \\
\hline Fikret Şeneş & General Guro & Halide Yenen & $\begin{array}{l}\text { İbrahim } \\
\text { Minnetoğlu }\end{array}$ & $\begin{array}{l}\text { Kanuni Sultan } \\
\text { Süleyman }\end{array}$ \\
\hline Kemal Yalçın & $\begin{array}{l}\text { Kutalmış } \\
\text { Süleyman Şah }\end{array}$ & $\begin{array}{l}\text { Kutluk Bilge Kül } \\
\text { Kağan Han }\end{array}$ & Lady Craven & $\begin{array}{ll}\text { I. } & \text { I. } \\
& \text { Mehmet }\end{array}$ \\
\hline Mehmet Akif Ersoy & Mete Han & Mevlana & Mimar Jachmund & $\begin{array}{l}\text { Mimar Kemaleddin } \\
\text { Bey }\end{array}$ \\
\hline $\begin{array}{l}\text { Mimar Muslihiddin } \\
\text { A } \breve{a} a\end{array}$ & Mimar Vedat Tek & $\begin{array}{l}\text { Mustafa Kemal } \\
\text { Atatürk }\end{array}$ & Nazım Hikmet & Necip fazıl Kısakürek \\
\hline Nergis Biray & $\begin{array}{l}\text { Neşet Ertaş } \\
\text { (Bozkırın Tezenesi) }\end{array}$ & Nizamülmülk & Osman Bey & $\begin{array}{l}\text { Philippe du } \\
\text { Fresnecanaye }\end{array}$ \\
\hline Saruca Paşa & Selçuk Bey & Suat Batur & Sultan Alparslan & Teoman \\
\hline Thomas Allom & Urbain Usta & Yaşar Kemal & Yunus Emre & Zeynep Kaya \\
\hline
\end{tabular}

Kitapta 50 meşhur kişi yer almaktadır. 7 isim yabancı kişilerdir. Mustafa Kemal Atatürk adı kitapta verilmektedir. Tarihi Türk devletlerinin kurucuları, sultanları kitapta adı geçen meşhur isimlerdendir. Bumin Kağan Han, Kutluk Bilge Kül Kağan Han, Sultan Alparslan bunlardan birkaçıdır. Fatih Sultan Mehmet ve Kanuni Sultan Süleyman da kitapta anılmaktadır. Bunların yanında Âşık Veysel, Neşet Ertaş, Barış Manço Türk müziğinin sembolleri olarak kitapta bulunmaktadır. Mehmet Akif Ersoy vardır. Yunus Emre, Mevlana kitapta unutulmamıştır. Cumhuriyet dönemi Türk edebiyatının önemli isimleri Necip Fazıl, Nazım Hikmet ve Yaşar Kemal de kitapta geçmektedir. Ve sadece burada geçmektedir.

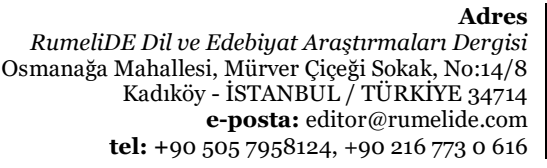

Address

RumeliDE Journal of Language and Literature Studies Osmanağa Mahallesi, Mürver Çiçeği Sokak, No:14/8 Kadıköy - ISTANBUL / TURKEY 34714

e-mail: editor@rumelide.com,

phone: +90 505 7958124, +90 2167730616 
104 / RumeliDE Journal of Language and Literature Studies 2021.Ö10 (October)

Examination of proper nouns in Turkish and Turkish culture textbooks as cultural elements / Ş. Yeşilyurt (pp. 81-117)

Tablo 86. Mekân adları

\begin{tabular}{|c|c|c|c|c|c|c|}
\hline Afrika & $\begin{array}{l}\text { Akdamar } \\
\text { Adası }\end{array}$ & $\begin{array}{l}\text { Akdamar } \\
\text { Kilisesi }\end{array}$ & Akdeniz & $\begin{array}{l}\text { Altın Elbiseli } \\
\text { Adam }\end{array}$ & Anadolu & $\begin{array}{l}\text { Ani } \\
\text { harabeleri }\end{array}$ \\
\hline $\begin{array}{l}\text { Anvers } \\
\text { Limanı }\end{array}$ & Aphrodisias & $\begin{array}{l}\text { Arap } \\
\text { Yarımadası }\end{array}$ & Asya & Avrupa & Ayder Yaylası & Balkanlar \\
\hline Bodrum & Bodrum & $\begin{array}{l}\text { Çanakkale } \\
\text { Boğazı }\end{array}$ & Çeşme & Çiçekdağ1 & $\begin{array}{l}\text { Çifte } \\
\text { Minareli } \\
\text { Medrese }\end{array}$ & Çin Seddi \\
\hline Çumra & Dicle & Didim & Domaniç & Efes & Ege & Emirdağ \\
\hline Erciyes & Esenköy & Eskihisar & Fethiye & Firat & Horasan & $\begin{array}{l}\text { Ihlamur } \\
\text { Kasrı }\end{array}$ \\
\hline $\begin{array}{l}\text { İstanbul } \\
\text { Boğazı }\end{array}$ & İznik & Kapadokya & Karadeniz & Kirtıllar & Kuşadası & $\begin{array}{l}\text { Londra } \\
\text { Kulesi }\end{array}$ \\
\hline Malazgirt & Marmara & Marmaris & Milet & Nemrut Dağg 1 & $\begin{array}{l}\text { Nizamiye } \\
\text { Medresesi }\end{array}$ & $\begin{array}{l}\text { Orhun } \\
\text { Abideleri }\end{array}$ \\
\hline Orta Anadolu & Orta Asya & Orta Doğu & $\begin{array}{l}\text { Palandöken } \\
\text { Dağı }\end{array}$ & Pergamon & Pokut Yaylası & Sardes \\
\hline Sirkeci Garı & Söğüt & $\begin{array}{l}\text { Tonyukuk } \\
\text { Anitı }\end{array}$ & Topçular & Trakya & Tuz Gölü & Uludağ \\
\hline Van Gölü & Yeni & & & & & \\
\hline
\end{tabular}

Kitapta 65 mekân adı geçmektedir. 5’i Türkiye dışındaki mekânlardır. 60 mekân Türkiye’de tarihi ve coğrafi özellik taşıyan yerlerdir. Türkiye'nin bölgelerinin adı kitapta geçmektedir. İstanbul Boğazı, Nemrut Dağı, Tuz Gölü, Erciyes Dağı Türkiye'nin sembol mekânları olarak kitapta bulunmaktadır. Altın Elbiseli Adam bir mekân değildir ancak müzede sergilendiği için mekân adı içerisinde verilmiştir.

Tablo 87. Bayram adları

\section{Kurban Bayramı}

Kitapta geçen tek bayram ismi dini bir bayram olan Kurban Bayramı’dır. Dini bayramlar başlığı altında bir metinde bu bayramların özelliği verilmiş ve daha sonra 18 sayfa Kurban Bayramı'nın tüm dini ve kültürel özellikleri anlatılmıştır.

Tablo 88. Önemli günler

\begin{tabular}{|c|c|c|c|c|}
\hline Arife Günü & $\begin{array}{l}\text { Avrupa Gençlik } \\
\text { Olimpik Kış } \\
\text { Festivali }\end{array}$ & Çanakkale Savaşları & Dünya Kukla Günü & 1.Dünya Savaşı \\
\hline Kavimler Göcü & Kurtuluș Savașı & Lale Festivali & Narenciye Festivali & Ramazan \\
\hline
\end{tabular}

Kitapta 10 önemli gün adı geçmektedir. Çanakkale savaşları, Kurtuluş Savaşı tarihimizin önemli mücadeleleridir. Arife Günü ilk kez bu kitapta adı geçen dinî ve kültürel olarak önemli bir gündür. Narenciye ve Lale Festivali de yöresel özellik taşıyan önemli günlerdir.

Tablo 89. Eser ve kahraman adları

$\begin{array}{llll}\text { İstiklal Marşı } & \text { Karagöz Hacivat } & \text { Kutadgu Bilig } & \text { Leyla ile Mecnun } \\ \text { Sakarya Türküsü } & \text { Siyasetname } & \end{array}$

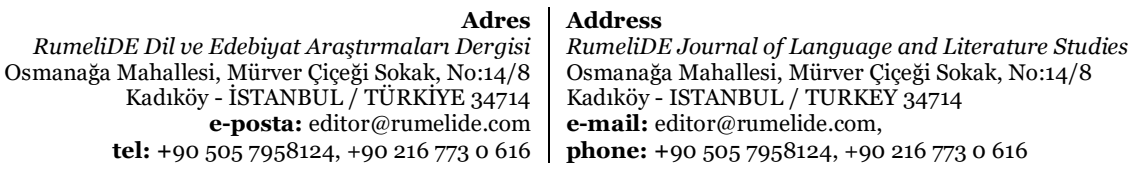


Kitapta 4 eser 2 kahraman adı olmak üzere toplam 6 özel ad geçmektedir. İstiklal Marşı kitabın içinde de eser olarak anılmıştır. Eserler "Kutadgu Bilig ve Siyasetname" 11. yüzylla ait Türk edebiyat ve tarihinin önemli eserleridir.

Tablo 9o. Kurum adları

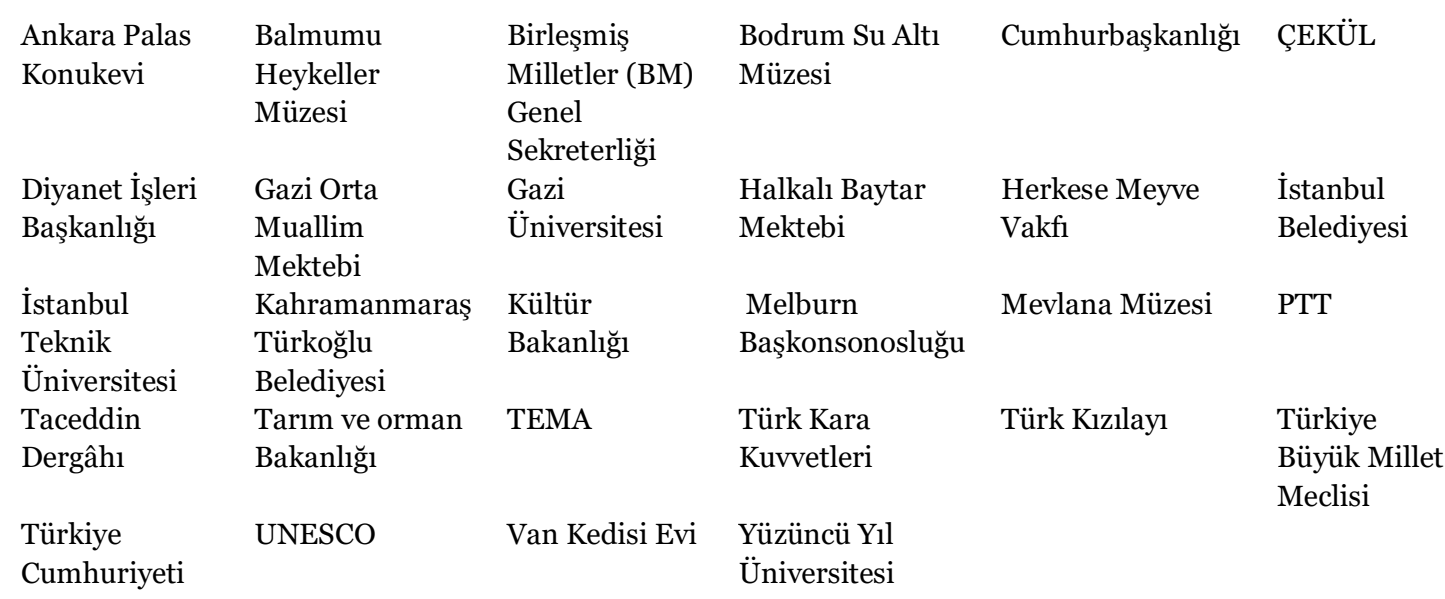

Kitapta 28 kurum adı geçmektedir. Türkiye Cumhuriyeti yine bu kitapta da temel kurum olarak sayılmıştır. Türkiye Büyük Millet Meclisi, Türk Kızılayı, Kültür Bakanlığı adı verilmesi gereken önemli kurumlardır. İlk kez “ Gazi Üniversitesi” adı bu kitapta geçmektedir.

Türkçe ve Türk Kültürü-6 kitabında 229 özel ad geçmektedir. \% 28’i mekân adı, \%23’ü şehir adları, \%22'si meşhur kişiler, \%12'si kurum adıdır. Diğer oranlara \%10'unun altındadır. 15 başlıktan 12'si kitapta mevcuttur. "Gazete ve Dergi Adları, Kanal Adları, Hayvan Adları" kitapta yer almayan başlıklardır. Kitabın sayfa sayısına oranla kitapta geçen özel adların oranı \% 139’dur.

\section{Türkçe ve Türk kültürü 7}

Kitap 167 sayfadan oluşmaktadır. Gençliğe hitabe ve İstiklal Marşı kitap girişinde bulunmaktadır.

Tablo 91. Kişi adları

Ahmet Ayşe Hakan Mehmet Sofi

Kitapta 7 özel ad geçmektedir. 2 isim de yabancı isimdir. Diğer 4 isim Türkiye'de yaygın kullanılan isimlerdir. Ancak bunlardan sadece 1'i kız ismidir.

Tablo 92. Ülke adları

\begin{tabular}{|c|c|c|c|c|c|c|}
\hline $\mathrm{ABD}$ & Almanya & Avusturalya & $\begin{array}{l}\text { Babür } \\
\text { İmparatorluğu }\end{array}$ & $\begin{array}{c}\text { Bosna } \\
\text { Hersek }\end{array}$ & Göktürkler & Hindistan \\
\hline İsveç & Japonya & Moğolistan & Osmanlı & Selçuklu & Suriye & Türkiye \\
\hline
\end{tabular}

Kitapta 15 ülke ismi geçmektedir. Bunlardan "Göktürkler, Selçuklu ve Osmanlı" Türklerin kurdukları devletler olarak kitapta yer almaktadır. Yine Babür İmparatorluğu da tarihteki bir Türk devleti olarak kitapta mevcuttur. Diğer ülkeler Türk nüfusun bulunduğu ülkelerdir.

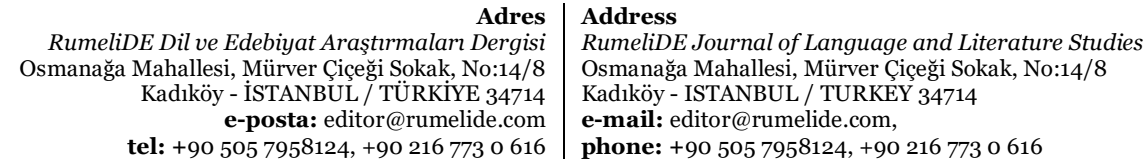


Tablo 93. Şehir adları

$\begin{array}{llllllll}\text { Adana } & \text { Adıyaman } & \text { Afyonkarahisar } & \text { Agra } & \text { Ă̆rı } & \text { Aksaray } & \text { Amasya } & \text { Ankara } \\ \text { Antalya } & \text { Ardahan } & \text { Artvin } & \text { Aydın } & \text { Balıksir } & \text { Bartın } & \text { Batman } & \text { Bayburt } \\ \text { Bilecik } & \text { Bingöl } & \text { Bitlis } & \text { Bolu } & \text { Burdur } & \text { Bursa } & \text { Çanakkale } & \text { Çankırı } \\ \text { Çorum } & \text { Denizli } & \text { Diyarbakır } & \text { Düzce } & \text { Edirne } & \text { Elazı̆ } & \text { Erzincan } & \text { Erzurum } \\ \text { Eskişehir } & \text { Gaziantep } & \text { Giresun } & \text { Gümüşhane } & \text { Hakkâri } & \text { Hatay } & \text { Iğdır } & \text { Isparta } \\ \text { İstanbul } & \text { İmir } & \text { Kahramanmaraş } & \text { Karabük } & \text { Karaman } & \text { Kars } & \text { Kastamonu } & \text { Kayseri } \\ \text { Kırıkkale } & \text { Kırklareli } & \text { Kırşehir } & \text { Kilis } & \text { Kocaeli } & \text { Konya } & \text { Kütahya } & \text { Malatya } \\ \text { Manisa } & \text { Mardin } & \text { Mersin } & \text { Mostar } & \text { Muğla } & \text { Muş } & \text { Nevşehir } & \text { Niğde } \\ \text { Ordu } & \text { Osmaniye } & \text { Rize } & \text { Sakarya } & \text { Samsun } & \text { Siirt } & \text { Sinop } & \text { Sivas } \\ \text { Şanlıurfa } & \text { Şırnak } & \text { Tekirdağ } & \text { Tokat } & \text { Trabzon } & \text { Tunceli } & \text { Uşak } & \text { Van } \\ \text { Yalova } & \text { Yozgat } & \text { Zonguldak } & & & & & \end{array}$

Kitapta 83 il adı geçmektedir. Türkiye'nin tüm illeri kitapta verilmiştir. 2 şehir farklı ülkelerde yer almaktadır.

Tablo 94. Milliyet ve mensubiyet adları
Boşnak
Danimarkalı
Hirvat
Rus
Türk
Yörükler

Kitapta 5 milliyet adı ve 1 mensubiyet (Yörükler) adı geçmektedir. “Türk” adı kitapta geçmektedir.

Tablo 95. Dil adları

Türkçe

Kitapta geçen tek dil adı Türkçedir.

Tablo 96. Dinle ilgili özel adlar

$\begin{array}{lllll}\text { Allah } & \text { Hristiyan } & \text { İslamiyet } & \text { Kur'an-ı Kerim } & \text { Müslüman } \\ \begin{array}{l}\text { Peygamber } \\ \text { Efendimiz }\end{array} & \text { Rab } & \text { Tanrı } & \text { Yahudi } & \end{array}$

Kitapta dinle ilgili 9 özel ad geçmektedir. Tanrı ismi ilk kez bu kitapta verilmiştir. İslamiyet'e ait önemli isimler yanında diğer iki büyük dine ait mensubiyet adları da kitapta verilmiştir.

Tablo 97. Meşhur kişiler

\begin{tabular}{|c|c|c|c|c|c|c|c|}
\hline Abdi paşa & Alex Dixon & Ali A $\breve{g a}$ & \multicolumn{2}{|c|}{ Ali Akar } & Ali Göçer & Bayram Baş & Bilge Kağan \\
\hline Cahit Sitkı & Cemil & Cinüçen & \multirow{2}{*}{\multicolumn{2}{|c|}{$\begin{array}{l}\text { Çoşkun } \\
\text { Ertepınar }\end{array}$}} & Engin Beksaç & Ercümend & Evliya çelebi \\
\hline & & & & & & & \\
\hline Faize Yoldaş & $\begin{array}{l}\text { Faruk Nafiz } \\
\text { Çamlıbel }\end{array}$ & $\begin{array}{l}\text { Fatih Sultan } \\
\text { Mehmet }\end{array}$ & \multicolumn{2}{|c|}{ Fethi Gedikli } & $\begin{array}{l}\text { Galip Naşit } \\
\text { Arı }\end{array}$ & $\begin{array}{l}\text { Gökhan } \\
\text { Özcan }\end{array}$ & Gökhan Tok \\
\hline Güray Ervin & Hacı Taşan & Halide Sert & \multicolumn{2}{|c|}{$\begin{array}{l}\text { Halil } \\
\text { Altuntaş }\end{array}$} & III. Mustafa & III.Selim & İshak paşa \\
\hline $\begin{array}{l}\text { İsmail } \\
\text { Karagöz }\end{array}$ & Karacaoğlan & Kül Tigin & \multicolumn{2}{|c|}{$\begin{array}{l}\text { Lady } \\
\text { Montegu }\end{array}$} & Mahmut Han & $\begin{array}{l}\text { Mehmet } \\
\text { Fatih } \\
\text { Müftüoğlu }\end{array}$ & $\begin{array}{l}\text { Mehmet } \\
\text { Kurudayıoğlu }\end{array}$ \\
\hline \multirow[t]{2}{*}{ Melis Sincer } & $\begin{array}{l}\text { Mevlana } \\
\text { Celaleddin } \\
\text { rumi }\end{array}$ & $\begin{array}{l}\text { Mimar } \\
\text { Hayreddin }\end{array}$ & \multicolumn{2}{|c|}{ Mimar Sinan } & Mircan Kaya & $\begin{array}{l}\text { Mustafa } \\
\text { Kemal } \\
\text { Atatürk }\end{array}$ & $\begin{array}{l}\text { Mustafa } \\
\text { Kutlu }\end{array}$ \\
\hline & $\begin{array}{r}\text { RumeliDE Dilve } \\
\text { Osmanağa Mahalles } \\
\text { Kadıöy } \\
\text { tel: }+90\end{array}$ & $\begin{array}{l}\text { biyat Araşttrmal } \\
\text { lürver Ciçeği Soka } \\
\text { STANBUL / TÜRI } \\
\text { osta: editor@rur } \\
7958124,+9021\end{array}$ & $\begin{array}{l}\text { Adres } \\
\text { Dergisi } \\
\text { No:14/8 } \\
\text { E } 34714 \\
\text { ide.com } \\
73 \text { o } 616\end{array}$ & \multicolumn{4}{|c|}{$\begin{array}{l}\text { Address } \\
\text { RumeliDE Journal of Language and Literature Studies } \\
\text { Osmanağa Mahallesi, Mürver Çiceği Sokak, No:14/8 } \\
\text { Kadıköy - ISTANBUL / TURKEY } 34714 \\
\text { e-mail: editor@rumelide.com, } \\
\text { phone: +90 505 7958124, +90 } 216773 \text { o } 616\end{array}$} \\
\hline
\end{tabular}




\begin{tabular}{|c|c|c|c|c|c|c|}
\hline $\begin{array}{l}\text { Mustafa } \\
\text { Yoğurtçu }\end{array}$ & $\begin{array}{l}\text { Muzaffer } \\
\text { Sarı̈̈zen }\end{array}$ & $\begin{array}{l}\text { Mürselli } \\
\text { Hacı }\end{array}$ & Naz Elkorek & $\begin{array}{l}\text { Nurten } \\
\text { Bengü Aksoy }\end{array}$ & $\begin{array}{l}\text { Orhan } \\
\text { Yorgancı }\end{array}$ & $\begin{array}{l}\text { Ömer } \\
\text { Seyfettin }\end{array}$ \\
\hline Rufat Ilgaz & $\begin{array}{l}\text { Sait Faik } \\
\text { Abasıyanık }\end{array}$ & $\begin{array}{l}\text { Samim } \\
\text { Bilgen }\end{array}$ & $\begin{array}{l}\text { Süleyman } \\
\text { Faruk } \\
\text { Göncüoğlu }\end{array}$ & Şah Cihan & $\begin{array}{l}\text { Şükrü Oktay } \\
\text { Kılıç }\end{array}$ & $\begin{array}{l}\text { Taşkın } \\
\text { Soysal }\end{array}$ \\
\hline Tonyukuk & $\begin{array}{l}\text { Türkolog W. } \\
\text { Radloff }\end{array}$ & V. Thomsen & Vahap Akbaş & Yasin Sert & $\begin{array}{l}\text { Yavuz } \\
\text { Bahadıroğlu }\end{array}$ & Yunus Emre \\
\hline Zahide İmer & $\begin{array}{l}\text { Zeki } \\
\text { Tunaboylu }\end{array}$ & $\begin{array}{l}\text { Zeliha } \\
\text { Kumbasar }\end{array}$ & & & & \\
\hline
\end{tabular}

Kitapta 66 meşhur isim geçmektedir. Bunlardan 4’ü yabancı isimlerdir. 62'si Türk büyükleri, yazarlar, şairler, müzisyenlerden oluşmaktadır. Mustafa Kemal Atatürk adı kitapta verilmiştir. Bilge Kağan, Tonyukuk, Kül Tigin Fatih Sultan Mehmet adı geçen önemli devlet adamlarıdır. Mevlana ve Yunus Emre kitapta anılmaktadır. Kitapta diğer kitaplarda yer almayan yazarlar da bulunmaktadır: Ömer Seyfettin, Rıfat Ilgaz, Sait Faik Abasıyanık, Faruk Nafiz Çamlıbel, Cahit Sıtkı Tarancı, Yavuz Bahadıroğlu. Evliya Çelebi de ismi geçen Türk kültürünün önemli bir şahsiyetidir. Mimar Sinan da eserleriyle Türk tarihinin unutulmaz şahsiyetlerindendir. İlk kez bu kitapta anılmıştır ve bir de son kitapta adı geçmektedir. “ Karacaoğlan" ismi de sadece bu kitapta geçmektedir.

Tablo 98. Mekân adları

\begin{tabular}{|c|c|c|c|c|c|c|}
\hline Adapazarı & Afrika & Ağırnas & Ağrı Dağı & $\begin{array}{l}\text { Ahi Çelebi } \\
\text { Camisi }\end{array}$ & Akdeniz & Anadolu \\
\hline $\begin{array}{l}\text { Atik Valide } \\
\text { Camisi }\end{array}$ & Avrupa & $\begin{array}{l}\text { Ayazma } \\
\text { Cami }\end{array}$ & Beyazıt & Çamlıbel & Çıldır & $\begin{array}{l}\text { Çifte } \\
\text { Minareli } \\
\text { Medrese }\end{array}$ \\
\hline Çingene Kız & Çukurova & Doğu Bayazıt & Erciyes Dağı & $\begin{array}{l}\text { Firat ve Dicle } \\
\text { Nehirleri }\end{array}$ & Galata & Göbeklitepe \\
\hline Gönen & $\begin{array}{l}\text { Hatuniye } \\
\text { Medresesi }\end{array}$ & Ilgaz Dağı & $\begin{array}{l}\text { Ilgaz Dağları } \\
\text { Milli Parkı }\end{array}$ & $\begin{array}{l}\text { İshak Paşa } \\
\text { sarayı }\end{array}$ & Karadeniz & Laleli \\
\hline $\begin{array}{l}\text { Mağlova Su } \\
\text { Kemeri }\end{array}$ & $\begin{array}{l}\text { Mihrimah } \\
\text { Sultan } \\
\text { Camisi }\end{array}$ & $\begin{array}{l}\text { Mostar } \\
\text { Köprüsü }\end{array}$ & Nallihan & $\begin{array}{l}\text { Neratva } \\
\text { Nehri }\end{array}$ & Orhun Vadisi & Ödemiş \\
\hline $\begin{array}{l}\text { Rüstem Paşa } \\
\text { Camisi }\end{array}$ & Sarıbeyler & Sarıköy & $\begin{array}{l}\text { Selimiye } \\
\text { Cami }\end{array}$ & $\begin{array}{l}\text { Seyyit Hasan } \\
\text { Paşa } \\
\text { Medresesi }\end{array}$ & Sivrihisar & $\begin{array}{l}\text { Süleymaniye } \\
\text { camisi ve } \\
\text { külliyesi }\end{array}$ \\
\hline $\begin{array}{l}\text { Şehzade } \\
\text { Cami }\end{array}$ & Tac Mahal & $\begin{array}{l}\text { Taksim } \\
\text { Maksemi Kuş } \\
\text { Evi }\end{array}$ & & $\begin{array}{l}\text { Taptuk Emre } \\
\text { Dergâhı }\end{array}$ & $\begin{array}{l}\text { Toros } \\
\text { Dağları }\end{array}$ & Tuz Gölü \\
\hline Uludă & Üsküdar & Van Gölü & $\begin{array}{l}\text { Yeni Valide } \\
\text { Cami }\end{array}$ & & & \\
\hline
\end{tabular}

Kitapta 52 mekân adı geçmektedir. 3 mekân Türkiye dışındadır. 50 mekân Türkiye'dedir. Türkiye'nin bölgelerine dair isimlendirmeler kitapta yoktur. Ancak farklı bölgelerde yer alan tarihî, coğrafî mekân isimleri kitapta bulunmaktadır. Özellikle İstanbul'daki tarihi camilerin çoğunun adı verilmiştir. Süleymaniye Camisi ve Külliyesi Mihrimah Sultan Camisi Rüstem Paşa Camisi Şehzade Cami, Yeni Valide Cami bunlardır. Selimiye Cami ve diğer camiler Mimar Sinan’ın eserleridir.

Tablo 99. Bayram adları

Paskalya Bayramı

Ramazan Bayramı
Roş Aşana Bayramı

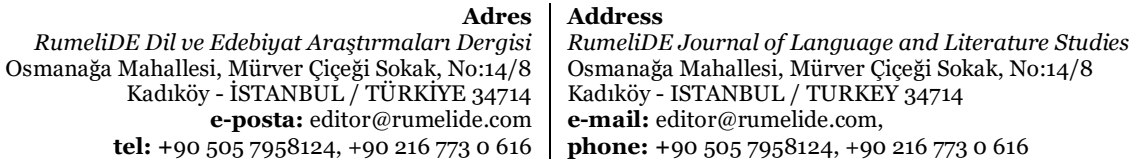

RumeliDE Dil ve Edebiyat Araştırmaları Dergisi adı̈̈̈ Mür tel: +90 505 7958124, +902167730616 
Kitapta 4 bayram adı geçmektedir. İki bayram İslam kültürüne, diğer bayramlar Yahudilik ve Hristiyanlık kültürüne aittir. Adı verilen dini bayramlardan Ramazan ve Şeker Bayramı zaten aynı bayramı ifade ettiği için kitapta Türklere ait tek bayram adının geçtiği kabul edilebilir.

Tablo 10o. Önemli günler

\begin{tabular}{|c|c|c|c|}
\hline Arife Günü & Aşure Günü & Birinci Dünya Savaşı & Boşnak Hırvat Savaşı \\
\hline İstanbul'un Fethi & Ramazan & & \\
\hline
\end{tabular}

Kitapta 6 önemli gün adı geçmektedir. İstanbul'un Fethi hem dünya tarihi için hem de Türk tarihi için büyük bir olaydır. Bir çağı kapatıp yeni bir çağı açmıştır. Bir devleti İmparatorluk yapan olaydır. Bu sebeple Türk kültürü kitaplarında adının geçmesi önemlidir. Sadece bu kitapta geçmektedir. Arife ve Aşure Günü dini özellik taşıyan iki önemli gün olarak kitapta bulunmaktadır.

Tablo 1o1. Eser ve kahraman adları

\begin{tabular}{|c|c|c|c|c|c|}
\hline Affan Dede & Han Duvarları & $\begin{array}{l}\text { Hüzün ve } \\
\text { Tesadüf }\end{array}$ & Kaşağı & Orhun Abideleri & Orhun Yazitları \\
\hline $\begin{array}{l}\text { Resimli Türk } \\
\text { Edebiyatı Tarihi }\end{array}$ & Seyahatname & Son Kuşlar & Tonyukuk Anıtı & Türk Dili Tarihi & \\
\hline
\end{tabular}

Kitapta eser veya kahraman adı olarak 11 özel ad geçmektedir. Orhun Abideleri, Orhun Yazıtları adıyla iki farklı şekilde kitapta bulunmaktadır. Evliya Çelebi’nin meşhur eseri Seyahatname de kitapta mevcuttur. Kaşağı, Hüzün ve Tesadüf adlı hikâye kitaplarına da kitapta yer verilmiştir. Resimli Türk Edebiyatı Tarihi ve Türk Dili Tarihi akademik anlamada bilgi edinmek isteyenler için önemli kaynaklardır. Onların da adı dipnot şeklinde kitapta geçmektedir.

Tablo 102. Kurum adları

$\begin{array}{llll}\begin{array}{l}\text { Babaeski Devlet } \\ \text { Hastanesi }\end{array} & \text { Boğaziçi Üniversitesi } & \text { Columbia Üniversitesi } & \text { Çankaya Belediyesi } \\ \text { EGO } & \begin{array}{l}\text { İstanbul Büyükşehir } \\ \text { Belediyesi }\end{array} & \begin{array}{l}\text { İzmir Büyükşehir } \\ \text { Belediyesi }\end{array} & \text { Kalkı̈nma İnisiyatifleri } \\ \text { Kızılay } & \text { Leylek Vakfi } & \text { New Wonders 7 Vakfı } & \text { Suyu Soğutan Vakıf } \\ \text { Türk Dil Kurumu } & \text { UNESCO } & & \end{array}$

Kitapta 14 kurum adı geçmektedir. 2'si Türkiye'ye ait değildir. Kızılay ve Türk Dil Kurumu devlete ait resmi kurumlar olarak kitapta bulunmaktadır. Bunun yanında şehirlere ait belediye isimleri de kitapta geçmektedir.

Tablo 103. Gazete adı

Hürriyet

Sabah

Kitapta 2 gazete ismi yer almaktadır.

Tablo 104. Kanal adı

Habertürk

TRT Haber

Kitapta 2 kanal adı geçmektedir. Biri devlet, biri özel kanaldır.

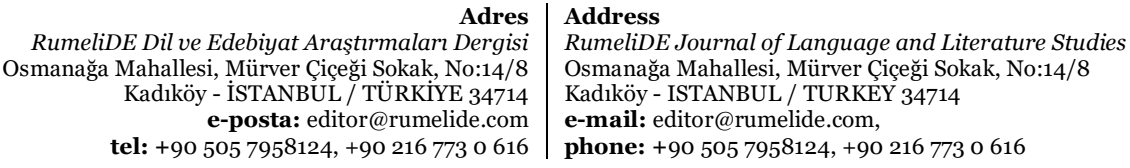

Adres
RumeliDE Dil ve Edebiyat Araştırmaları Dergisi Kadlë, Mürver Çiçegi Sokak, No:14/8 tel: +90 $5057958124,+902167730616$ 
Türkçe ve Türk Kültürü-7 kitabında 277 özel ad geçmektedir. \%30’u şehir adları, \%24'ü meşhur kişiler, \%19’u mekân adlarıdır. Diğer adların oranı \%10’un altındadır. 15 başlıktan 14’ü kitapta ter almaktadır. Sadece "Hayvan Adı" başlığına ait özel ad kitapta yoktur. Kitabın sayfa sayısına göre geçen özel adların kitaba oranı \% 168'dir.

\section{Türkçe ve Türk kültürü 8}

Kitap 238 sayfadan oluşmaktadır. Gençliğe Hitabe ve İstiklal Marşı 10 kıta şeklinde kitapta yer almaktadır.

Tablo 105. Kişi adları

Ayşe Ceren Ceyda Dursun Hans

Kitapta 6 özel isim geçmektedir. İsimlerden biri yabancıların kullandığı özel isimdir.

Tablo 106. Ülke adları

$\begin{array}{llllll}\text { ABD } & \text { Almanya } & \begin{array}{l}\text { Asya Hun } \\ \text { Devleti }\end{array} & \text { Avusturalya } & \text { Belçika } & \text { Bosna-Hersek } \\ \text { Bulgaristan } & \text { Ermenistan } & \text { Güney Kore } & \text { Gürcistan } & \text { Hindistan } & \text { Hollanda } \\ \text { Irak } & \text { İran } & \text { İspanya } & \text { İsviçre } & \text { Kazakistan } & \text { Kosava } \\ \text { Kuzey Kore } & \text { Küba } & \text { Macaristan } & \text { Makedonya } & \text { Mısır } & \text { Moğolistan } \\ \text { Moldava } & \text { Nahçıvan } & \begin{array}{l}\text { Osmanlı } \\ \text { İmparatorluğu }\end{array} & \text { Özbekistan } & \text { Portekiz } & \text { Selçuklu Devleti } \\ \text { Sovyet Rusya } & \text { Suriye } & \text { Timur Devleti } & \text { Türkistan } & \text { Türkiye } & \text { Yunanistan }\end{array}$

Kitapta 36 ülke adı geçmektedir. Türkiye’nin komşularının verildiği tek kitaptır. Yine kitapta "Asya Hun Devleti”, "Selçuklu Devleti”, “Osmanlı İmparatorluğu” şeklinde tarihte Türklerin kurduğu devletler mevcuttur.

Tablo 107. Şehir adları

$\begin{array}{llllllll}\text { Albany } & \text { Ankara } & \text { Bağdat } & \text { Balkesir } & \text { Belh } & \text { Berlin } & \text { Budapeşte } & \text { Buhara } \\ \text { Cheratte } & \text { Denizli } & \text { Diyarbakır } & \text { Elhamra } & \text { Eskişehir } & \text { Fojnica } & \text { Havana } & \text { Isparta } \\ \text { İstanbul } & \text { İzmir } & \text { Konstantinopolis } & \text { Malatya } & \text { Merv } & \text { Milodraz } & \text { Paris } & \text { Selanik } \\ \text { Semerkant } & \text { Sivas } & \text { Şiraz } & \text { Utrecht } & \text { Üsküp } & \text { Van } & \text { Washington } & \end{array}$

Kitapta 31 şehir mevcuttur. 18 şehir farklı ülkelerde yer almaktadır. İstanbul eski adı Konstantinopolis olarak da kitapta geçmektedir. Ankara ve İstanbul ismi kitapta mevcuttur.

Tablo 108. Milliyet ve mensubiyet adları

$\begin{array}{llll}\text { Alman } & \text { Bektaşi } & \text { Iraklı } & \text { İspanyollar } \\ \text { Macar } & \text { Malatyalılar } & \text { Nazi } & \text { Suriyeli } \\ \text { Türk } & \text { Yemenli } & & \end{array}$

Kitapta 10 milliyet ve mensubiyet adı geçmektedir. Türk adı kitapta mevcuttur. Türkiye'de kullanılan mensubiyet adlarından olan Malatyalılar ve Bektaşi dışındaki özel adlar farklı ülkelere ait milliyeti ifade etmektedir.

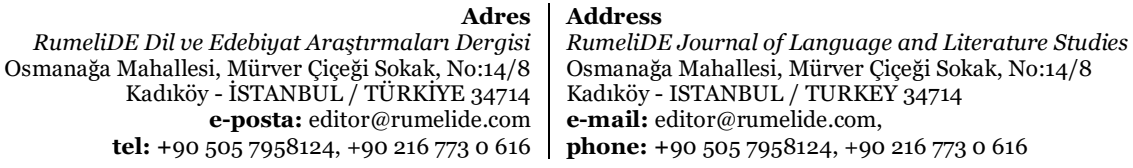


110 / RumeliDE Journal of Language and Literature Studies 2021.Ö10 (October)

Examination of proper nouns in Turkish and Turkish culture textbooks as cultural elements / Ş. Yeşilyurt (pp. 81-117)

Tablo 109. Dil adları

$\begin{array}{llll}\text { Arapça } & \text { Ermenice } & \text { Farsça } & \text { Fransızca } \\ \text { Gagavuz Türkçesi } & \text { Osmanlı Türkçesi } & \text { Rumca } & \text { Türkçe }\end{array}$

Kitapta 8 dil adı geçmektedir. Türkçe, Osmanlı Türkçesi ve Gagavuz Türkçesi dışındaki dil isimleri farklı ülkelerde konuşulan dil adlarıdır.

Tablo 110. Dinle ilgili özel isimler

$\begin{array}{llllll}\text { Allah } & \text { Berat Gecesi } & \text { Berat Kandili } & \text { Büyük Tufan } & \text { Enbiya Suresi } & \text { Fransiskenler } \\ \text { Hac } & \text { Hak } & \begin{array}{l}\text { Hazreti } \\ \text { Peygamber }\end{array} & \text { Hızır } & \text { Hristiyan } & \text { Hz. Muhammed } \\ \text { Hz. Nuh } & \begin{array}{l}\text { İlyas } \\ \text { Peygamber }\end{array} & \text { İslam } & \text { Íslamiyet } & \text { Kadir Gecesi } & \text { Kur'an-ı Kerim } \\ \text { Mevlid Kandili } & \text { Mirac Kandili } & \text { Müslümanlar } & \text { Ortadoks } & \begin{array}{l}\text { Peygamber } \\ \text { Efendimiz }\end{array} & \text { Regaib Kandili }\end{array}$

Yahudi Zümer Suresi

Kitapta dinle ilgili 26 özel ad geçmektedir. Bu kategoride en çok özel ad bu kitapta yer almaktadır. 4 özel isim İslamiyet dışındaki dinlerle ilgili özel adlardır. Özel kandil geceleri ilk kez bu kitapta verilmiştir. Bu geceler, önemli günler başlı̆̆ altında da verilebilirdi ancak diğer kitaplarda da hiç geçmediği için dine ait özel isimler başlı̆̆ı altında verilmiştir. Hz. Muhammed, Peygamber Efendimiz, Hazreti Peygamber ifadesiyle üç farklı şekilde kitapta yer almıştır. Kur’an surelerinden bazılarına da ilk kez bu kitapta yer verilmiştir. Yine "Hac" kelimesi de sadece burada bulunmaktadır.

Tablo 111. Meşhur kişiler

\begin{tabular}{|c|c|c|c|c|c|}
\hline $\begin{array}{l}\text { Ahmet Bekir } \\
\text { Palazoğlu }\end{array}$ & $\begin{array}{l}\text { Ahmet Yaşar } \\
\text { Ocak }\end{array}$ & Albert Einstein & Ali Akbaş & Ali Atay & Ali Kuşçu \\
\hline $\begin{array}{l}\text { Assılk Veysel } \\
\text { Şatıroğlu }\end{array}$ & Atatürk & Baki & $\begin{array}{l}\text { Barboros } \\
\text { Hayrettin Paşa }\end{array}$ & Barış Manço & Bernard Lewis \\
\hline Bilal Eryılmaz & Cahit Arf & Can Ulkay & Çetin Tekindor & Dursun Fakih & El-Cezeri \\
\hline $\begin{array}{l}\text { Elefterios } \\
\text { Venizelos }\end{array}$ & Erhan Afyoncu & Ertuğrul Gazi & Evliya Çelebi & Farabi & Faruk Aksoy \\
\hline $\begin{array}{l}\text { Fatih Sultan } \\
\text { Mehmet }\end{array}$ & $\begin{array}{l}\text { Franklin } \\
\text { Roosevelt }\end{array}$ & Fuzuli & Gazali & Gülnihal Yolcu & H. Salih Zengin \\
\hline II. Bayezid & II. Mahmut & II. Murat & $\begin{array}{l}\text { İ. Hakkı } \\
\text { Uzunçarşılı }\end{array}$ & İbn-i Sina & $\begin{array}{l}\text { İbrahim Agâh } \\
\text { Çubukçu }\end{array}$ \\
\hline İbrahim Paşa & İnci macun & İskender Pala & İsmail Hacıŏlu & John B. Bogart & $\begin{array}{l}\text { Kanuni Sultan } \\
\text { Süleyman }\end{array}$ \\
\hline $\begin{array}{l}\text { Kaşgarlı } \\
\text { Mahmut }\end{array}$ & Kim Seol & Litvinof & Lütfi Paşa & Mete han & Mevlana \\
\hline $\begin{array}{l}\text { Mim Kemal } \\
\text { Öke }\end{array}$ & $\begin{array}{l}\text { Mimar Ahmet } \\
\text { Paşa }\end{array}$ & $\begin{array}{l}\text { Mimar } \\
\text { hayrettin }\end{array}$ & Mimar Sinan & $\begin{array}{l}\text { Muhteşem } \\
\text { Süleyman }\end{array}$ & $\begin{array}{l}\text { Mustafa Kemal } \\
\text { Atatürk }\end{array}$ \\
\hline $\begin{array}{l}\text { Muzaffer } \\
\text { Özgüleş }\end{array}$ & Mümtaz Mahal & Observer & Osman Bey & Ömer Hayyam & Salih Bozok \\
\hline $\begin{array}{l}\text { Selahattin } \\
\text { Tansel }\end{array}$ & $\begin{array}{l}\text { Sokullu } \\
\text { Mehmet Paşa }\end{array}$ & $\begin{array}{l}\text { Süleyman } \\
\text { Dilbirliği }\end{array}$ & Şah Cihan & Şeyh Edebali & $\begin{array}{l}\text { Tevfik Rüştü } \\
\text { Aras }\end{array}$ \\
\hline Timur & Ulu Önder & Uluğ Bey & Uzun Hasan & $\begin{array}{l}\text { Winston } \\
\text { Churchil }\end{array}$ & $\begin{array}{l}\text { Yavuz Sultan } \\
\text { selim }\end{array}$ \\
\hline \multicolumn{3}{|c|}{$\begin{array}{r}\text { Adres } \\
\text { RumeliDE Dil ve Edebiyat Arassturmaları Dergisi } \\
\text { Osmanağa Mahallesi, Mürver Ciçĕgi Sokak, No:14/8 } \\
\text { Kadıköy - İSTANBUL / TÜRKIYE } 34714 \\
\text { e-posta: editor@rumelide.com } \\
\text { tel: }+90 \text { 505 7958124, +90 } 216773 \text { o } 616\end{array}$} & \multicolumn{3}{|c|}{$\begin{array}{l}\text { Address } \\
\text { RumeliDE Journal of Language and Literature Studies } \\
\text { Osmanağa Mahallesi, Mürver Ciçeği Sokak, No:14/8 } \\
\text { Kadıköy - ISTANBUL / TURKEY } 34714 \\
\text { e-mail: editor@rumelide.com, } \\
\text { phone: +90 505 7958124, +90 } 216773 \text { o } 616\end{array}$} \\
\hline
\end{tabular}




$\begin{array}{llll}\text { Yavuz Unat } \quad \text { Yılmaz Öztuna } & \text { Yunus Emre } & \text { Zeki Müren } & \text { Zeynep } \\ & & & \text { Korkmaz }\end{array}$

Kitapta 77 meşhur isim bulunmaktadır. Kitaptaki meşhur isim sayısı da diğer kitaplara göre çoktur. Bu isimlerden 9’u yabancı kişilerdir. Diğerleri Türkiye ve Türk tarihi için önemli olan şahsiyetlerdir. Atatürk, Mustafa Kemal Atatürk ve Ulu Önder isimleri kitapta mevcuttur. Ulu Önder isminin kullanıldı̆̆ı tek kitaptır. Türk büyüklerinden Mete Han, Ertuğrul Gazi, Osman Bey, Yavuz Sultan Selim, Fatih Sultan Mehmet, Kanuni Süleyman kitapta yer almaktadır. Sultan Süleyman, Muhteşem Süleyman olarak da kitapta zikredilmektedir. Mevlana, Yunus Emre kitapta yerini almıştır. Zeki Müren, Türk müziği için önemli bir isimdir ve kitapta mevcuttur.

Tablo 112. Mekân adları

\begin{tabular}{|c|c|c|c|c|c|}
\hline Afrika & Akdeniz Bölgesi & Ani Harabeleri & Artuklu sarayı & Asya & Asya \\
\hline Atatürk Anıtı & Atatürk Büstü & Atatürk Caddesi & Atatürk Heykeli & $\begin{array}{l}\text { Atatürk } \\
\text { Meydanı }\end{array}$ & Avrupa \\
\hline $\begin{array}{l}\text { Ayasofya } \\
\text { Medreseleri }\end{array}$ & Ayder & Balıklı Göl & Balkanlar & Balkanlar & Bandırma \\
\hline $\begin{array}{l}\text { Barbaros } \\
\text { Mahallesi }\end{array}$ & $\begin{array}{l}\text { Bergama Antik } \\
\text { kenti }\end{array}$ & $\begin{array}{l}\text { Beşikçizade } \\
\text { Tekkesi }\end{array}$ & Beyoğlu & $\begin{array}{l}\text { Boğaziçi } \\
\text { Köprüsü }\end{array}$ & $\begin{array}{l}\text { Buhara } \\
\text { Kütüphanesi }\end{array}$ \\
\hline Çamlıhemşin & $\begin{array}{l}\text { Çanakkale } \\
\text { Boğazı }\end{array}$ & $\begin{array}{l}\text { Efes Antik } \\
\text { Kenti }\end{array}$ & Ege & Erdek & Galata \\
\hline $\begin{array}{l}\text { Gül Baba } \\
\text { Türbesi }\end{array}$ & Gümüşsuyu & $\begin{array}{l}\text { Güneydoğu } \\
\text { Anadolu }\end{array}$ & Ihlara Vadisi & İstanbul Boğazı & Kafkasya \\
\hline Kapadokya & $\begin{array}{l}\text { Karagöz Bey } \\
\text { Medresesi }\end{array}$ & Keban Barajı & Kuzey Afrika & Latin Amerika & Midas Tapınağ \\
\hline $\begin{array}{l}\text { Mostar } \\
\text { Köprüsü }\end{array}$ & Nemrut Dağ & $\begin{array}{l}\text { Nizamiye } \\
\text { Medreseleri }\end{array}$ & Ongözlü Köprü & Orta Asya & Pamukkale \\
\hline Pamukkale & Peribacaları & Safranbolu & Selimiye Cami & $\begin{array}{l}\text { Semaniye } \\
\text { Medresesi }\end{array}$ & $\begin{array}{l}\text { Sultanahmet } \\
\text { Cami }\end{array}$ \\
\hline $\begin{array}{l}\text { Sümela } \\
\text { manastırı }\end{array}$ & Tac Mahal & Taksim & Taşkışla & Trakya & $\begin{array}{l}\text { Truva Antik } \\
\text { kenti }\end{array}$ \\
\hline $\begin{array}{l}\text { Uluğ Bey } \\
\text { Krateri }\end{array}$ & Urla & Üsküdar & $\begin{array}{l}\text { Veysel Karani } \\
\text { Türbesi }\end{array}$ & $\begin{array}{l}\text { Yedigöller Milli } \\
\text { parkı }\end{array}$ & Yeşilırmak \\
\hline
\end{tabular}

Kitapta 66 mekân adı vardır. 6 mekân farklı ülkelere ait yerlerdir. Başka ülkelerde yer alan Atatürk Büstü, Heykeli, Caddesi ve Meydanı kitapta tanıtılmıştır. Türkiye'nin bölgelerinden bazıları kitapta verilmiştir. Yine Türkiye'nin farklı bölgelerinde yer alan mekân isimleri kitapta yer almıştır.

Tablo 113. Bayram Adları
Kurban bayramı
Nevruz bayramı
Ramazan Bayramı

Kitapta 3 bayram adı geçmektedir. Kitapta resmî bayram adları mevcut değildir.

Tablo 114. Önemli Günler

$\begin{array}{lllll}\text { Aşure Günü } & \text { Kore Savaşı } & \text { II. Dünya Savaşı } & \text { Hıdrellez } & \text { Ruz-ı Hızır } \\ \text { Karpuz Festivali } & \text { Aydın Deve } & \text { 15 Temmuz } & 18 \text { Aralık } & \\ & \text { Güreşleri Festivali } & & \text { Uluslararası } & \\ & & & \text { Göçmenler Günü }\end{array}$

\footnotetext{
RumeliDE Dil ve Edebiyat Araştırmaları Dergisi Osmanağa Mahallesi, Mürver Çiçeği Sokak, No:14/8 Kadıköy - İSTANBUL / TÜRKIYE 34714 e-posta: editor@rumelide.com

Address

RumeliDE Journal of Language and Literature Studies Osmanağa Mahallesi, Mürver Çiçeği Sokak, No:14/8 Kadıköy - ISTANBUL / TURKEY 34714

e-mail: editor@rumelide.com, tel: +90 505 7958124, +90 2167730616 phone: +90 505 7958124, +90 2167730616
} 
Kitapta 9 önemli gün vardır. 15 Temmuz, birlik ve beraberliğimizin hatırlandığı önemli bir gün olarak kitapta mevcuttur. Bu gün uzun adıyla sadece Türk kültürü 5 kitabında yer almıştır. Yine Hıdırellez ismi de sadece bu kitapta verilmiştir.

Tablo 115. Eser ve kahraman adları

\begin{tabular}{|c|c|c|c|c|c|}
\hline 3'te 3 Tarih & Ayla & Dede Korkut & $\begin{array}{l}\text { Dede Korkut } \\
\text { Hikâyeleri }\end{array}$ & $\begin{array}{l}\text { Divan-I Lügati’t } \\
\text { Türk }\end{array}$ & Fetih 1453 \\
\hline $\begin{array}{l}\text { İstanbul } \\
\text { Üniversitesi } \\
\text { Tarihi }\end{array}$ & $\begin{array}{l}\text { Karagöz ve } \\
\text { Hacivat }\end{array}$ & Korkut Ata & $\begin{array}{l}\text { Mehmetçik } \\
\text { Kutlu Zafer }\end{array}$ & Osmanlı Tarihi & $\begin{array}{l}\text { Pelin Çift İle } \\
\text { Gündem Ötesi }\end{array}$ \\
\hline Seyahatname & $\begin{array}{l}\text { TDV İslam } \\
\text { Ansiklopedisi }\end{array}$ & Tip kanunu & $\begin{array}{l}\text { Türk Halk } \\
\text { Edebiyatı El } \\
\text { Kitabı }\end{array}$ & & \\
\hline
\end{tabular}

Kitapta eser ve kahraman adı olarak 16 özel isim geçmektedir. TRT'de yer alan 2 program ve 1 dizi ismi bunlardan üçüdür. "Dede Korkut” kahraman ve eser olarak kitapta yer almaktadır.

Tablo 116. Kurum adları

\begin{tabular}{|c|c|c|c|c|}
\hline AFAD & Afet Geçici Kent & Ankara Üniversitesi & $\begin{array}{l}\text { Atatürk Araştırma } \\
\text { Merkezi }\end{array}$ & Avrupa Birliği \\
\hline Başbakanlık & $\begin{array}{l}\text { Başbakanlık Devlet } \\
\text { arşivleri Genel } \\
\text { Müdürlüğgü }\end{array}$ & Birleşmiş Milletler & Cumhurbaşkanlığı & $\begin{array}{l}\text { Din Hizmetleri } \\
\text { Müşavirliği }\end{array}$ \\
\hline $\begin{array}{l}\text { Diyarbakır } \\
\text { Büyükşehir } \\
\text { Belediyesi }\end{array}$ & EBA & Eğitim müşavirliği & $\begin{array}{l}\text { Göç İdaresi Genel } \\
\text { Müdürlüğü }\end{array}$ & İçişleri Bakanlığ \\
\hline $\begin{array}{l}\text { İstanbul } \\
\text { Üniversitesi }\end{array}$ & $\begin{array}{l}\text { İTÜ( İstanbul } \\
\text { Teknik } \\
\text { Üniversitesi) }\end{array}$ & $\begin{array}{l}\text { Kültür Tanıtma } \\
\text { Müşavirliği }\end{array}$ & Meclis & Merkez Bankası \\
\hline Oxford Üniversitesi & Paris Üniversitesi & $\begin{array}{l}\text { T.C. Dışişleri } \\
\text { Bakanlığı }\end{array}$ & TİKA & $\begin{array}{l}\text { TRT Genel } \\
\text { Müdürlüğü }\end{array}$ \\
\hline $\begin{array}{l}\text { TRT Yayıncıllk } \\
\text { Tarihi Müzesi }\end{array}$ & Türk Büyükelçiliği & $\begin{array}{l}\text { Türk Kültür } \\
\text { Merkezi }\end{array}$ & $\begin{array}{l}\text { Türkiye } \\
\text { Cumhuriyeti Mostar } \\
\text { Başkonsolosluğu }\end{array}$ & $\begin{array}{l}\text { Uluslararası } \\
\text { Astronomi Derneği }\end{array}$ \\
\hline UNESCO & $\begin{array}{l}\text { Yönetim sistemi } \\
\text { (AFKEN) }\end{array}$ & $\begin{array}{l}\text { Yunus Emre } \\
\text { Enstitüsü }\end{array}$ & & \\
\hline
\end{tabular}

Kitapta 33 kurum adı geçmektedir. AFAD, TİKA, Yunus Emre Enstitüsü gibi Türkiye’yi yurt dışında temsil eden önemli kurum isimleri kitapta verilmiştir. Özellikle yurt dışında yaşayan Türklerle ilgili kurum isimleri "Göç İdaresi Genel Müdürlüğü, T.C. Dışişleri Bakanlığı, Eğitim Müşavirliği, Kültür Tanıtma Müşavirliği” kitapta mevcuttur.

Tablo 117. Dergi ve Gazete Adları

\begin{tabular}{|c|c|c|c|}
\hline $\begin{array}{l}\text { Ana Sözü Gazetesi } \\
\text { (Moldava) }\end{array}$ & Avrupa'nın Sesi Gazetesi & Bilim Çocuk (Tübitak) & Cumhuriyet \\
\hline Diyanet Çocuk Dergisi & Hürriyet & Kosova Haber Gazetesi & Merhaba Gazetesi \\
\hline $\begin{array}{l}\text { New York Sun (Niv York } \\
\text { San) gazetesi }\end{array}$ & Post Gazetesi & PTT Çocuk Dergisi & Resmî Gazete \\
\hline Son Posta & Takvim-i Vekâyi & TRT Çocuk Dergisi & \\
\hline
\end{tabular}

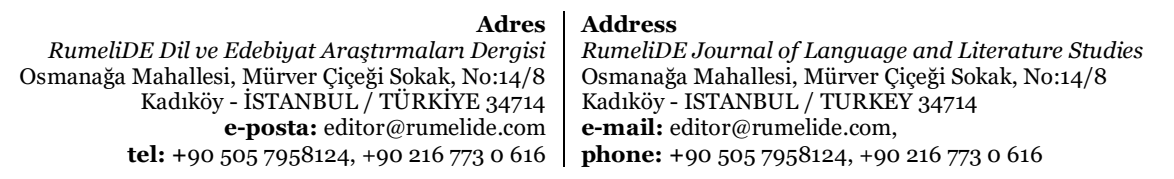


Kitapta 15 gazete ve dergi adı geçmektedir. Yine en çok bu kitapta bu başlıktaki özel adlar mevcuttur. Türkiye'deki gazetelerin yanında yurt dışında farklı ülkelerde Türkçe olarak çıkan gazete isimleri de kitapta verilmiştir.

Tablo 119. Kanal Adları

$\begin{array}{lllll}\text { TRT } & \text { TRT1 } & \text { TRT2 } & \text { TRT Avaz } & \text { TRT Belgesel } \\ \text { TRT OKUL } & \text { TRT Çocuk } & \text { TRT GAP } & \text { TRT World } & \end{array}$

Kitapta 9 kanal adı vardır. 9 kanal da devlete ait kanal isimleridir.

Türkçe ve Türk Kültürü-8 kitabında 343 özel ad geçmektedir. Bunları \%22'si meşhur kişiler, \%19’u mekân adı, \%10’u ülke adıdır. Diğer oranlar \%10’un altındadır ve yakın miktardadır. 15 başlık maddesinden 14'ü kitapta geçmektedir. Kitapta yer almayan başlık "Hayvan Adı" maddesidir. Kitabın sayfa sayısına oranla \% 149 oranında özel ad kitapta yer almaktadır.

10 kitabın içinde geçen özel adların sayfa sayısına oranı, grafikle şu şekildedir:

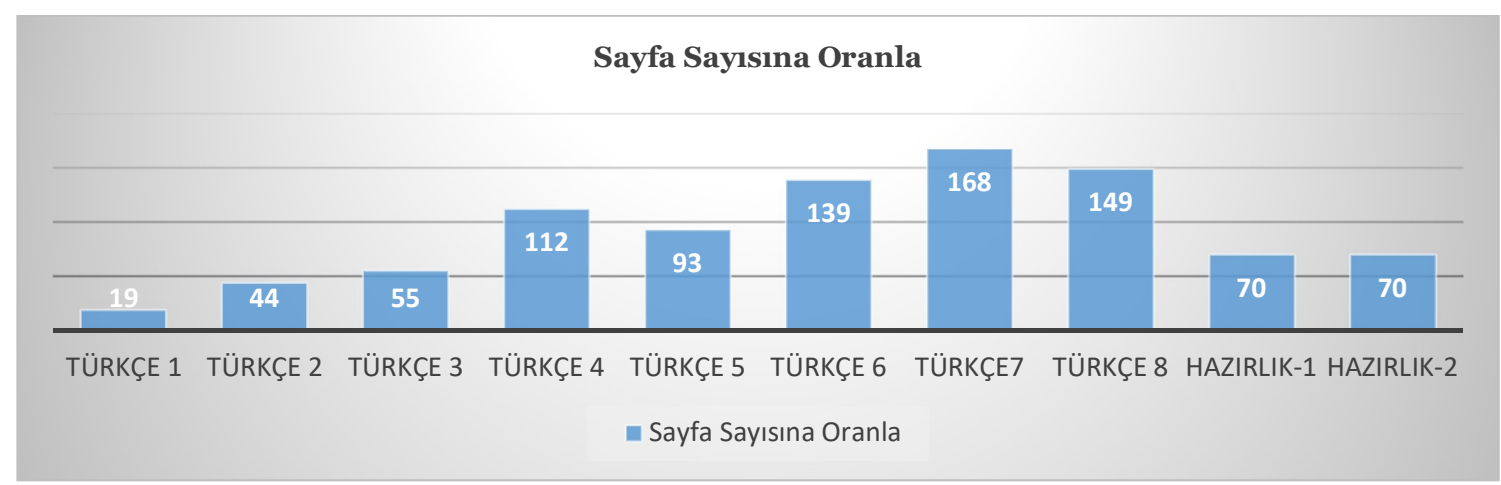

Şekil 2: Özel adların sayfa sayısına oranı

Bu grafiğe göre özel adların dağılımı genel olarak kitap seviyesine göre doğru orantılı bir şekilde artmıştır. Ancak Türkçe 4 ve Türkçe 3 kitapları arasındaki artışta oransal bir uçurum bulunmaktadır. $\% 55^{\prime}$ lik bu oransal boşluk, \%46'lık bir oranla Türkçe-5 ile Türkçe-6 arasında da vardır. 1-2-3-4 kitapları arasında basamaksal olarak artan düzey, 4. kitaptan sonra inişli çıkışlı bir seyir göstermektedir. Bu da özel adların dağılımında farklılık ve artış düzeyinde eşitlik olmadığını göstermektedir. Grafikte hazırlık kitapları, 8 temel kitaptan sonra sıralanmıştır böylece 8 kitabın artışı daha net ortaya konulmuştur. Hazırlık kitaplarının sayfa sayıları ve içindeki özel ad sayıları birbirinden farklılık göstermektedir buna rağmen özel adların dağılımındaki yüzdelik oran aynıdır. Bu da Hazırlık kitaplarının kendi içinde bir standardı olduğunu göstermektedir.

\section{Sonuç ve tartışma}

İbni Haldun ve A. Hamdi Tanpınar'a atfen söylenen 'coğrafya kaderdir' sözü; toplumun nerede, nasıl bir coğrafi ortamda, hangi şartlarda yaşadığı yaşam tarzlarına ve kültüre doğrudan tesir ettiğini ifade etmektedir (Alver, 2010: 46). Kültür; dil, din, tarih, gelenek ve görenek; bir topluma ait maddi ve manevi tüm değerler manzumesidir (Bostancı, 1995: 18). Yabancı kültürlerin kendilerini ilk gösterdiği alan, kişi ve yer adlarıdır (Şenel 2017: 73). Dolayısıyla adlandırmalar, özel adlar, kültürel simgelerdir. Bu doğrultuda Türkçe ve Türk Kültürü kitaplarında geçen özel adların incelendiği bu çalışmada özel adların

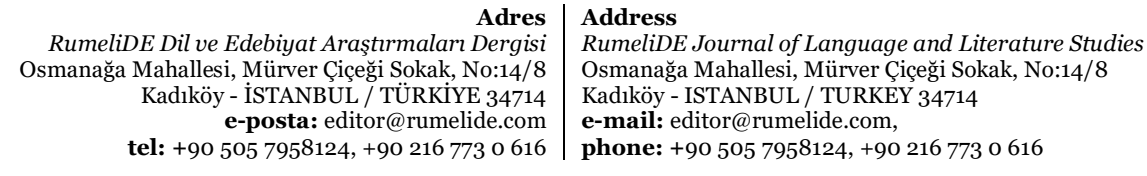


dă̆̆lımında ve çeşitliliğinde kitaplarda farklılıklar olduğu tespit edilmiştir. Tek tek kitaplardan elde edilen sonuçlar şu şekildedir:

Türkçe ve Türk Kültürü Hazırlık-1 kitabında en çok geçen özel ad%49’luk dilimle şahıs isimleridir. Özel adların dağılımında orantısızlık tespit edilmiştir. Kitaptaki dağılımın diğer özel adlarla orantılı olması kültürel unsurların artmasını sağlayacaktır. Kitapta 15 ana başlık maddesinden 11’i yer almaktadır. Kitapta sadece iki milliyet adı geçmektedir. Kitabın adının "Türk Kültürü” olmasına rağmen kitapta "Türk" kelimesi değil sadece Türkiyeli kelimesi yer almaktadır. Meşhur Kişiler başlı̆̆ı altında "Mustafa Kemal Atatürk" adı kitapta şahıs olarak geçmemektedir. Ancak mekân isimleri içinde "Anıtkabir" ve "Atatürk Caddesi" ne yer verilmiştir. Kitapta film, çizgi film, kitap adı ve kahramanları 9 özel isim olarak tespit edilmiştir. Bunların içinde sadece "Keloğlan" Türk kültürüne ait bir masal kahramanıdır. Türk kültürüne ait eser ve kahraman adlarının verilmesi gerekirdi. "Dinle İlgili Özel Adlar, Kurum Adları, Gazete ve Dergi Adları, Kanal Adları” başlıklarına ait özel ad kitapta yoktur.

Türkçe ve Türk Kültürü-1 kitabında en çok geçen özel ad \%52'lik dilimle şahıs adıdır. Şahıs adlarında bir yığılma tespit edilmiştir. Bu da kitaptaki özel adların dağılımındaki orantısızlığı göstermektedir. Kitapta 15 maddeden 8’i mevcuttur. Kitapta 2 ülke adı yer almaktadır. Farklı ülke isimlerine yer verilmemesi sadece Almanya olması kitabın sadece Almanya'da okutulan bir kitap olduğunu düşündürtmektedir. Kitapta geçen iki milliyet ismi bulunmaktadır. Kitapta ülke isimlerinde "Almanya" geçmesine rağmen milliyet olarak "Alman" değil "Japon" ifadesi geçmektedir. Kitapta yer alan tek bayram resmî bir bayram olan 23 Nisan'dır. Diğer bayramlar yoktur. "Dil Adı, Dinle İlgili özel Adlar, Önemli Günler, Kurum Adları, Gazete ve Dergi Adları, Kanal Adları, Hayvan Adları" kitapta mevcut değildir. Bu sebeple "Türkçe” dil adı olarak kitaptaki metinlerde geçmemektedir.

Türkçe ve Türk Kültürü-2 kitabında en çok geçen özel ad \%64'lük dilimle şahıs adıdır. 15 maddeden 11’i yer almaktadır. Kitapta 1 resmî bayram ve iki dini bayram adı toplam 4 bayram geçmektedir. Ramazan Bayramı kitapta şeker bayramı olarak da verilmiştir. Resmi olarak 23 Nisan verilmiştir. "Dinle İlgili özel Adlar, Kurum Adları, Gazete ve Dergi Adları, Kanal Adları” başlıklarına ait özel ad kitapta yoktur.

Türkçe ve Türk Kültürü-3 kitabında en çok geçen özel ad \%23'lük dilimle mekân adıdır. 11 ana başlık maddesi vardır. Kitapta 4 resmî bayram adı geçmektedir. Dinî bayram adları kitapta yer almamaktadır. Dil Adı, Gazete ve Dergi Adları, Kanal Adları, Hayvan Adları" kitabın içinde yer almayan özel ad başlıklarıdır. Kitabın içinde "Türkçe” dil adı hiç geçmemektedir.

Türkçe ve Türk Kültürü-4 kitabında en çok geçen özel ad \%3o'luk dilimle mekân adıdır. 12 madde yer almaktadır. İslamiyet adı ilk kez bu kitapta geçmektedir. Kitapta 4 bayram adı geçmektedir. Dördü de resmi bayramdır. Dini bayramların adları kitapta yer almamaktadır. "Önemli Günler, Hayvan Adları, Gazete ve Dergi Adları" kitapta yer almayan başlık maddeleridir.

Türkçe ve Türk Kültürü-5 kitabında en çok geçen özel ad \%17'lik dilimle meşhur kişi ve şehir adlarıdır. 12 ana başlık yer almaktadır. Kitapta 4 bayram adı geçmektedir. Dördü de resmî bayramdır. Dinî bayramlar kitapta ad olarak geçmemektedir. “15 Temmuz Demokrasi ve Millî Birlik Günü” tam adıyla verildiği tek kitaptır. Zaten iki kitapta geçmektedir. Kitapta 11 eser adı geçmektedir. Bu eserlerden 7'si "Dünya Çocuk Klasikleri” arasında yer alan hikâye kitaplarıdır (Define Adası, Martı, Çocuk Kalbi...). İstiklal Marşı, Safahat, Mesnevi, Mehter Marşı ise bizim edebiyatımıza ait kitapta adı geçen eserlerdir. Dünya çocuk edebiyatından 7 örneğin yer aldığı bir kitapta, Türk yazarların yazdığı birkaç çocuk

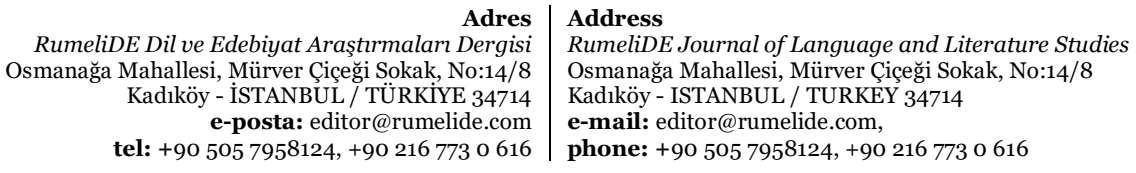


kitabının da eserler arasında anılması gerektiği düşünülmektedir. "Gazete ve Dergi Adları, Hayvan Adları" başlıkları kitapta yoktur.

Türkçe ve Türk Kültürü-6 kitabında en çok geçen özel ad \%28'lik dilimle mekân adlarıdır.12 ana madde mevcuttur. "Kuran-ı Kerim" ilk kez bu kitapta geçmektedir ve bu kitaptan itibaren diğer kitaplarda da verilmiştir. Ayrıca Hristiyanlık ve Şükran Günü de ilk kez bu kitapta verilmektedir. Cumhuriyet dönemi Türk edebiyatının önemli isimleri “Necip Fazıl, Nazım Hikmet ve Yaşar Kemal” de kitapta geçmektedir. Ve sadece burada geçmektedir. Kitapta geçen tek bayram ismi dini bir bayram olan Kurban Bayramı'dır. Dini bayramlar başlı̆̆ı altında bir metinde bu bayramların özelliği verilmiş ve daha sonra 18 sayfa Kurban Bayramı'nın tüm dini ve kültürel özellikleri anlatılmıştır. Arife Günü ilk kez bu kitapta adı geçen dinî ve kültürel olarak önemli bir gündür. "Gazete ve Dergi Adları, Kanal Adları, Hayvan Adları" başlıkları kitapta yoktur. 15 başlıktan 12'si kitapta mevcuttur.

Türkçe ve Türk Kültürü-7 kitabında en çok geçen özel ad \%3o’luk dilimle şehir adlarıdır. 14 ana başlık mevcuttur. Kitapta 7 özel ad geçmektedir. 2 isim de yabancı isimdir. Diğer 4 isim Türkiye'de yaygın kullanılan isimlerdir. Ancak bunlardan sadece 1’i kız ismidir. Tanrı ismi ilk kez bu kitapta verilmiştir. Mimar Sinan da eserleriyle Türk tarihinin unutulmaz şahsiyetlerindendir. İlk kez bu kitapta anılmıştır ve bir de son kitapta adı geçmektedir. "Karacaoğlan” ismi de sadece bu kitapta geçmektedir. Kitapta 4 bayram adı geçmektedir. İki bayram İslam kültürüne, diğer bayramlar Yahudilik ve Hristiyanlık kültürüne aittir. Adı verilen dini bayramlardan Ramazan ve Şeker Bayramı zaten aynı bayramı ifade ettiği için kitapta Türklere ait tek bayram adının geçtiği kabul edilebilir. İstanbul'un Fethi hem dünya tarihi için hem de Türk tarihi için büyük bir olaydır. Bir çağı kapatıp yeni bir çağı açmıştır. Bir devleti İmparatorluk yapan olaydır. Bu sebeple Türk kültürü kitaplarında adının geçmesi önemlidir. Sadece bu kitapta geçmektedir. Sadece "Hayvan Adı” başlı̆̆ına ait özel ad kitapta yoktur.

Türkçe ve Türk Kültürü-8 kitabında en çok geçen özel ad \%22'lik dilimle meşhur kişilerdir. 14 ana başlık mevcuttur. Türkiye'nin komşularının verildiği tek kitaptır. Atatürk, Mustafa Kemal Atatürk ve Ulu Önder isimleri kitapta mevcuttur. Ulu Önder isminin kullanıldığı tek kitaptır. Kitapta dinle ilgili 26 özel ad geçmektedir. Bu kategoride en çok özel ad bu kitapta yer almaktadır. 4 özel isim İslamiyet dışındaki dinlerle ilgili özel adlardır. Özel kandil geceleri ilk kez bu kitapta verilmiştir. Bu geceler, önemli günler başlı̆̆ altında da verilebilirdi ancak diğer kitaplarda da hiç geçmediği için dine ait özel isimler başlı̆̆ı altında verilmiştir. Hz. Muhammed, Peygamber Efendimiz ifadesiyle iki farklı şekilde kitapta yer almıştır. Kur'an surelerinden bazılarına da ilk kez bu kitapta yer verilmiştir. Yine "Hac" kelimesi de sadece burada bulunmaktadır. Kitapta 3 bayram adı geçmektedir. Kitapta resmî bayram adları mevcut değildir. Kitapta 15 gazete ve dergi adı geçmektedir. Yine en çok bu kitapta bu özel adlar mevcuttur. Türkiye'deki gazetelerin yanında yurt dışında farklı ülkelerde Türkçe olarak çıkan gazete isimleri de kitapta verilmiştir. Kitapta yer almayan başlık "Hayvan Adı" maddesidir.

Kitapların geneline baktığımızda Türk kültürüne ait özel adların verildiği ancak kitaplara dağılımında orantısızlık olduğu görülmektedir. Kitaplarda yer almayan başlık maddeleri, kitaptaki eksik kültür unsurlarının varlığını göstermektedir. Bundan sonra yazılacak olan kitaplarda özellikle tüm başlık maddelerini kapsayacak örneklerin yer alması millî kültür unsurlarının genelinin verilmesini sağlayacaktır. Ayrıca kitaplarda belli özel adlarda oluşan yığılma dikkati çekmektedir. Bu nedenle dengeli bir dağılım olduğunda da kültür unsurlarının her bir maddesi kitaplarda sergilenebilecektir.

2018 yllında MEB tarafından seviyelere göre hazırlanan Türkçe ve Türk Kültürü dersi öğretim programı, kültürel ögeler açısından genel çerçeveyi çizmiştir. Ancak buna rağmen çerçevedeki temaların seviyelere

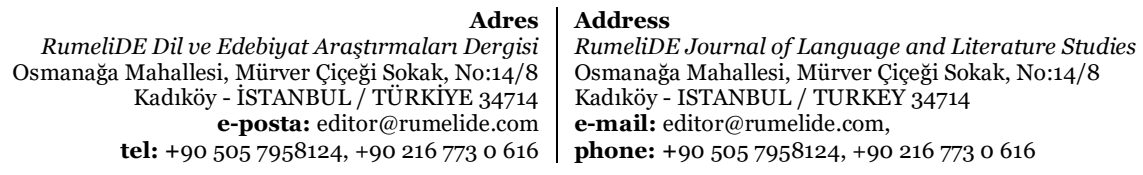


göre dağılımına uymayan kitaplar vardır. Yazılan kitaplarda öğretim programına dikkat edilmesi yazarların işini kolaylaştırıcı ve seviyelerin adım adım ilerleyişini sağlayan bir unsurdur. Bu çalışmayla kitaplarda verilecek kültür ögelerinin yer aldığı bir listeye ihtiyaç duyulduğu görülmektedir. Çerçeve programlarıyla birlikte hazırlanacak kültürel unsurlara ait özel adlar listesi, öğretmenlerin ve kitap yazarlarının işi kolaylaştıracak, hangi kültürel ögelerin verileceği hangilerinin verilmeyeceği karmaşasını da ortadan kaldıracaktır. Bazı istisnai görüşler bir kenara bırakılırsa, kültür ve kimlik konusu dün olduğu gibi bugün de önemini koruyan ve bundan sonra da koruyacak olan bir olgudur (Horata, 2017: 126). Küreselleşme ve iletişim araçlarının rüzgârıyla mahallî renkler birer birer kaybolurken, gelişmiş ülkeler ise kültürel miraslarını âdeta yeniden keşfetmeye, sürdürülebilir kalkınmanın temel araçlarından biri olarak gördükleri kültürel alana önemli yatırımlar yapmaya başlamışlardır. Bu tekelleşmeye karşı, her ülke gibi Türk devletlerinin de büyük kültürel miraslarını tanıtma ve yaymaya ağırlık vermesi gerekmektedir (Horata, 2017:125). Bir öneri olarak da kitaplardaki özel adlar, sıklık açsından kelimeler ele alınmamıştır bundan sonra yapılacak çalışmalarda özellikle "Türk, Türkiye, Türkçe" kelimelerinin her bir kitapta kaç kez kullanıldığı tespit edilebilir. Ayrıca özellikle Türk kültürü için "millet, millî, kültür" gibi kelimelerin de kitaplardaki metin ve bağlam içinde kullanımı bu kelimeler önem taşıdığı için tespit edilmelidir.

\section{Kaynakça}

Acipayaml,,O., (1992). Türk kültüründe ad koyma folklorunun morfolojik ve fonksiyonel yönlerden incelenmesi. VI. Milletlerarası Türk Halk Kongresi Bildirileri.

Aksan, D. (2015). Her yönüyle dil ana çizgileriyle dil bilim. Türk Dil Kurumu.

Altıntaş, A. (2015). Bir kültür unsuru olarak edebi eserlerdeki özel isimler ve onlarn çeviri problemleri (F. M. Dostoyevskïnin Suç ve Ceza" Romanı Üzerine). Yüksek Lisans Tezi. Kafkas Üniversitesi.

Alver K. (2010). Kültür sosyolojisi ve kültürel çalışmalar. İstanbul Üniversitesi Açlk ve Uzaktan Eğitim Fakültesi.

Anderson, J. M. (2007). On the grammar of names. Oxford.

Arı, G. (2019). Türkçe ve Türk kültürü 4 (ders kitabı). Milli Eğitim Bakanlığı.

Bayram, A. (2019). Yurt dışında Türkçe ve Türk kültürü öğretmek için hazırlanan kitaplarda ve ilgili öğretim programında millî kültür unsurları. Akademi.

Deniz, K. (2019). Türkçe ve Türk kültürü 5 (ders kitabı). Milli Eğitim Bakanlığı.

Doğan, Y. (2019). Türkçe ve Türk kültürü 6 (ders kitabı). Milli Eğitim Bakanlığı.

Durmuş, M. (2019). Türkçe ve Türk kültürü hazırlık 2 (ders kitabı). Milli Eğitim Bakanlığı.

Ekmekçi, V., Karadüz, A., (2015). Yurt dışında yaşayan iki dilli çocuklar için hazırlanan Türkçe ve Türk kültürü dersi kitabına eleştirel bir bakış. Turkısh Studies, 10(15), 361-378 DOI Number: http://dx.doi.org/10,7827/TurkishStudies.8976, p.361-378.

Göçer, A., (2012). Dil kültür ilişkisi ve etkileşimi üzerine. Türk Dili Dil ve Edebiyat Dergisi, 50-57.

Horata, O. (2017).Türk dünyasının kültürel ufukları: tarihsel bağlam içinde genel bir değerlendirme. Bilig, 82, 117-131.

Karadağ, Ö.. Baş, B.(2019).Türkçe ve Türk kültürü dersine dair ihtiyaç analizi. Sakarya Unıversıty Journal Of Education, 9(3), 434-454.

Karatay, H. (2019). Türkçe ve Türk kültürü 8 (Ders kitabı). Milli Eğitim Bakanlığı.

Keskin, H. K. (2019). Türkçe ve Türk kültürü 3 (ders kitabr). Milli Eğitim Bakanlığı.

Kolay, G. (2018). Yurt dışında yaşayan Türk çocukları için hazırlanmış Türkçe ve Türk kültürü ders kitaplarında kültürel ögeler. Bolu Abant İzzet Baysal Üniversitesi Eğitim Bilimleri Enstitüsü. Yüksek Lisans Tezi.

\footnotetext{
Adres Address

RumeliDE Dil ve Edebiyat Araşturmalar Dergisi $\quad$ RumeliDE Journal of Language and Literature Studies

Osmanağa Mahallesi, Mürver Çiçeği Sokak, No:14/8 $\quad$ Osmanağa Mahallesi, Mürver Çiçeği Sokak, No:14/8

Kadıköy - ÍSTANBUL / TÜRKIYE 34714 Kadıköy - ISTANBUL / TURKEY 34714

e-posta: editor@rumelide.com e-mail: editor@rumelide.com,

tel: +90 505 7958124, +90 2167730616 phone: +90 505 7958124, +90 2167730616
} 
Kurt, M., Temur, N. (2019). Türkçe ve Türk kültürü hazırlık 1 (ders kitabı). Milli Eğitim Bakanlığı. Kurudayığlu, M. (2019). Türkçe ve Türk kültürü 7 (ders kitabı). Milli Eğitim Bakanlığı.

MEB (2009). Yurt Dışındaki Türk Çocukları İçin Türkçe ve Türk Kültürü Dersi Öğretim Programı (110. Sinıflar). Talim ve Terbiye Kurulu Başkanlığı.

MEB (2018). Yurt dışındaki Türk çocukları için Türkçe ve Türk kültürü dersi öğretim programı (1-8. sinıflar). Ankara: Milli Eğitim Bakanlığı.

Sidekli, S. (2019). Türkçe ve Türk kültürü 1 (ders kitabı). Milli Eğitim Bakanlığı.

Şen, Ü. (2019). Türkçe ve Türk kültürü 2 (ders kitabı). Milli Eğitim Bakanlığı.

Ünalan, Ş. (2005). Dil ve kültür (3. baskı). Nobel.

Yıldırım, A. \& Şimşek, H. (2011). Sosyal bilimlerde nitel araştırma yöntemleri. Seçkin.

Adres
RumeliDE Dil ve Edebiyat Araşttrmaları Dergisi Osmanağa Mahallesi, Mürver Çiçeği Sokak, No:14/8 Kadıköy - İSTANBUL / TÜRKIYE 34714 e-posta: editor@rumelide.com tel: +90 $5057958124,+902167730616$
Address

RumeliDE Journal of Language and Literature Studies Osmanağa Mahallesi, Mürver Çiçeği Sokak, No:14/8

Kadıköy - ISTANBUL / TURKEY 34714

e-mail: editor@rumelide.com,

phone: +90 505 7958124, +90 2167730616 